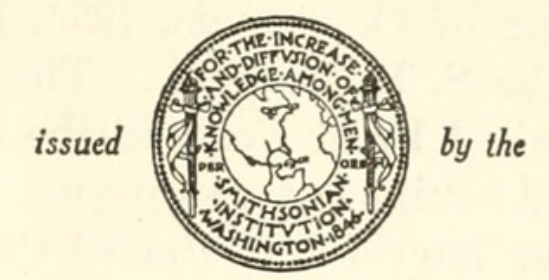

SMITHSONIAN INSTITUTION

U. S. NATIONAL MUSEUM

\title{
NOTES ON BIRDS OF THE GUATEMALAN HIGHLANDS
}

\section{By Alexander Wetmore}

MANY years ago the Smithsonian Institution was fortunate in receiving small collections of birds from the elevated plateau of western Guatamala from Dr. C. H. Van Patten and from Osbert Salvin, with a few scattered contributions from other sources. These came at a time when Central American birds were just beginning to be well known, and the material was highly valuable to the studies of Baird, Ridgway, and other ornithologists of the day. The representation of species, however, was far from complete, and many of the specimens did not have the detailed data required in modern studies. Therefore I welcomed an opportunity that came in the latter part of 1936 to visit Guatemala, both for the interesting studies that this offered and for the additions in needed material to the collections of the United States National Museum. My work covered the period from the latter part of October to the first days of December and, except for a few observations around Puerto Barrios, was confined to the highlands above an elevation of 3,200 feet. The region examined included the slopes of the volcanoes of Agua, Acatenango, and Fuego, the vicinity of the beautiful lake of Atitlán, and the mountains above Tecpam, including one trip to the highland region of Desconsuelo in the Department of Totonicapám. Attention was focused principally on the indigenous forms of the plateau and mountain area, and on the movements of the abundant migrant birds from North America. 


\section{ITINERARY}

In the early morning of October 25, 1936, I reached Puerto Barrios, Guatemala, on the S. S. Metapan. Through the assistance of Mr. Austin, of the United Fruit Co., and the courtesy of the Guatemalan officials my field equipment was passed through customs without delay, and an hour later I was aboard the train for Guatemala City, where I arrived that evening. Through Gerald A. Drew, Chargé d'Affaires ad interim in the temporary absence of the American Minister, I received from General Anzueto, Director General de la Policía Nacionál, a letter to the police officials of the country as well as a complimentary driver's permit, and from the Secretaría de Guerra an arms permit to cover my collecting guns. Delphino Sánchez Latour, of the Ministerio de Relaciones Exteriores, arranged for me a general letter of recommendation from the Minister of Finance. E. J. La Garde, of the United Fruit Co., was most courteous in various matters.

In Guatemala City I rented a car and on the evening of October 27 drove to Antigua across a low range of mountains, a journey that required an hour. Here my old friend Dr. Wilson Popenoe, director of agricultural experiments for the United Fruit Co., had placed at my disposal his home, the picturesque and comfortable Casa Colonial, built originally about 1635 , partly destroyed in an earthquake near the close of the eighteenth century, and then restored recently by Dr. and Mrs. Popenoe in a faithful presentation of its original form and furnished delightfully in the Spanish style of the early seventeenth century. With this as my home and faithful María, caretaker for the house, to prepare my meals and care for other comforts, I began my work in the field in Guatemala. Coronel Carlos Cipriani, Jefe Politico of the Departamento de Sacatepéquez, to whom I had letters from Mr. Drew and Mr. Latour, was most cordial, and on October $29 \mathrm{I}$ began my actual work in the field.

For two weeks I collected steadily in this interesting region. Dueñas and Canderas where I worked especially are classic localities through the early investigations of Osbert Salvin. The level country adjacent to Antigua was mainly in cultivation that extended up over the slopes of the mountains, but in ravines or on steep slopes above the fields were thickets and groves of trees. On the northward face of Volcán de Chimaltenango above Canderas I had easy access to a tract of heavy rain forest. Birds were scarce in this woodland, and I had better collecting lower down. On October $31 \mathrm{I}$ drove to Santa María de Jesús and climbed through little fields to 8,000 feet on Volcán de Agua. Toward Chimaltenango I found a region of milpas diversified with thickets, scattered woodland, and pastures, while on the southern slopes of Volcán de Fuego below Alotenango 
were great barrancas cut by the floods of the rainy season in beds of volcanic ash. In this latter desolate region burrowing owls, black phoebes, and occasional swallows were the main inhabitants. In the barren barrancas I walked in blazing sun with little cover. Still farther down beyond Alotenango at 3,200 feet, below the barrio of Las Lajas, there were coffee plantations beside a great barranca that harbored many interesting birds. The road continued on to Escuintla.

On November 9 I drove through Chimaltenango and Patzum to Panajachel, where I located in the Hotel Tsanyuyú on the shore of Lake Atitlán. The blue waters of this lake fill a deep valley and are bounded by slopes covered with milpas of maize, in places where the land sloped so abruptly that cultivation seemed impossible. The cones of Volcán San Pedro and Volcán Tolimán rose directly from the lake shore with others towering just beyond. I had come here especially to search for the large grebe Podilymbus gigas and devoted attention for the first 2 days to the lake itself, hunting from a launch powered with a decrepit engine whose occasional breakdowns gave me time to enjoy the beauties of the lake and its mountain background. I traveled along the northern and eastern shores where, except for the fill made by the Río Panajachel at the foot of its valley, the shores were steep and there were no beaches. Often the rock descended abruptly directly to the water, while in other places small shrubs and low trees lined the slopes. Occasionally a coarsestemmed reed grew out for a short distance into the water, and rarely there were scattered plants of a round-stemmed Scirpus. In bays of shallower water toward the east and toward the west this Scirpus was more abundant.

The narrow valley at Panajachel had little coffee plantations toward the lake and dense thickets on the slopes elsewhere, the valley floor being devoted to milpas (cornfields and truck gardens) and pastures, with low second growth where the flood plain of the stream was too stony for cultivation. The abrupt slopes on either side were accessible from steep trails that the Indians climbed as readily as goats.

On November 16 I crossed to Tecpam, which lies at an elevation of a little over 7,000 feet, near the site of ancient Iximché, the Indian capital of the region at the time of the Spanish Conquest. From here, with chains on the rear wheels of the auto, I climbed slowly through the mud of a steep and winding mountain road, which in the fog and steady rain seemed to rise without end, until I arrived at the Sierra Santa Elena, the estate of Axel Pira, whose house was at an elevation of nearly 9,500 feet. Here I was received with the most friendly hospitality, and here I found one of the most inter- 
esting regions for my work. On the surrounding slopes and above extended a great forest of cypress and pine, the former with trunks often 6 to 8 feet in diameter and summits that towered from 125 to 200 feet in the air. With their wide knowledge of the local avifauna my host and his son, Axel, Jr., gave every assistance in my work. While birds were less abundant than at lower elevations, they were of especial interest because of their peculiar type. In these mountains, in addition to species unknown in the north, there range representative races of a number of kinds of birds that are typical of the Rocky Mountains in the western United States, here at or near their southern limit. These include among others a hairy woodpecker, a golden-crowned kinglet, a crested jay, and a brown creeper. A species of junco was one of the most abundant birds. With these were the brilliant trogons, the strange woodhewers that climbed on the tree trunks like woodpeckers, brilliant mountain warblers, beautifully colored hummingbirds, and other species that one normally associates with the Central American avifauna.

Farther down the mountain at the Finca Chichivac, also owned by Señor Pira, were forests of oak and other deciduous trees mixed with pines, and here there was less of the almost continual fog and rain of the higher elevations. One evening at Sierra Santa Elena the fog cleared and the night air was sharp and cold. The following morning the ground was white with a heavy frost and the sky was clear. In the sunshine, most welcome after obscure days of fog, I climbed to a lookout point at 10,000 feet elevation, where I had a marvelous view over the mountains to the waters of Lake Atitlán, while as my eye followed the line of the horizon, I counted the cones of 12 volcanoes ranged in a great semicircle in the background.

On November 24, another day of brilliant sunshine, we drove to the elevated region of Desconsuelo, where we stopped about 14 kilometers from the town of Totonicapám. The elevation ranged from 10,000 to 10,600 feet, with open country on the high, rolling ridges, grown with grass or covered with low, dense thickets, and scattered trees. Forests of great pines came to 10,200 feet, among them occasional gnarled patriarchs fully 10 feet through. Little valleys where there were small streams of clear water often contained marshy cienagas. The sun was warm and bright, and the grass green, and the dark forests made a pleasing background. Birds were abundant, and I made an excellent collection.

On the return we visited the great rock of María Tecum, sacred to the Indians, standing on a mountain shoulder with a sheer drop of several hundred feet on its open face. From the summit there is a wonderful view across broad reaches of mountain and valley. 
On November 28 I left the friendly atmosphere of Sierra Santa Elena with regret that I might not remain longer and that noon arrived in Antigua. In the 2 days that remained to me I worked the tropical section at 3,200 feet below Alotenago, again studying and collecting many interesting birds.

The morning of December 1 I devoted to packing, and in the afternoon I moved to Guatemala City, and the following day made official visits that closed my work. December 3 I continued by train to Puerto Barrios. On the following morning $I$ crossed the bay in a dugout canoe with two men for a few hours collecting in the swampy thickets of a small island. That night, with all my specimens prepared, I was on board the S. S. Platano for the return trip to New York.

\section{NOTES ON NORTH AMERICAN MIGRANTS}

For the North American migrant birds that travel the land route beyond Mexico, Guatemala forms the lower section of a funnel, for here the mass separating the Atlantic and the Pacific Oceans is suddenly narrowed, and there is consequently a concentration of birds that at times is truly remarkable. More interesting still, because of this narrow land area, birds with summer homes in the eastern and in the western parts of the North American Continent mingled in mixed flocks. On certain days migrants predominated over the local residents, and it soon became evident that the native kinds ordinarily were secretive and that small birds seen flitting actively and openly among the branches were almost certain to be northern migrants. For identification and record I took examples of all, but to avoid shooting migrant birds needlessly it was necessary to examine carefully, often with binoculars, every bird that was seen to determine whether it was desired.

It was fascinating to me always to find species associated that in the North are separated by hundreds or even thousands of miles. As an example, black-throated green warblers of the East and Townsend's warblers of the West ranged in the same scattered bands, accompanied perhaps by such companions as black-billed cuckoos and rose-breasted grosbeaks of eastern range and western tanagers from the Rocky Mountains. Though familiar for years with all these in their northern homes, their intermingling here in Guatemala brought me always a sensation of surprise, as in my mind I associated them always with the far separated ranges in which I knew them in the distant North.

Many of these migrants were obviously in their wintering ground, while others as obviously were hurrying farther south. For the continuation of their journey there is no apparent reason except the 
urge to go to a definite region without regard to equal facilities for food and safety that might be encountered on the way. These latter travelers often seemed to pass in waves as for a day the woodlands would be filled with them and then they would disappear. By the middle of November this southern movement lessened in amount and in fact seemed to end. The migrants encountered later seemed to be settled in their winter homes.

\section{Family COLYMBIDAE}

\section{COLYMBUS NIGRICOLLIS CALIFORNICUS (Heermann)}

Podiceps Californicus Heermann, Proc. Acad. Nat. Sci. Philadelphia, vol. 7, 1854 (Apr. 12, 1855), p. 179 (California).

On November 9 I saw two on Lake Atitlán, near Panajachel. Other grebes seen were probably this species but were not certainly identified.

\section{COLYMBUS DOMINICUS BRACHYPTERUS Chapman: Mexican Grebe}

Colymbus dominicus brachypterus Chapman, Bull. Amer. Mus. Nat. Hist., vol. 12, Dec. 23, 1899, p. 256 (Lomita Ranch, Lower Rio Grande Valley, Texas).

On Lake Atitlán these small grebes are common along the shore so that I noted them daily from November 9 to 15 . One that I collected on November 12 was prepared as a skeleton. One or two pairs lived in a little bay near the hotel and were obviously mating at this season. Frequently I heard from them a low chattering note.

\section{PODILYMBUS GIGAS Griscom}

l'odilymbus gigas Griscom, Amer. Mus. Nov., No. 379, 1929, p. 5 (Panajachel, Lake Atitlán, Guatemala).

One of the reasons for my visit to Lake Atitlán was to search for this grebe, known only from this body of water. And on the afternoon of my arrival on November $9 \mathrm{I}$ was fortunate in securing a fine pair. At the hotel below Panajachel I arranged for a small launch with an engineer who was certain that he knew this bird. We cruised along the steep slopes of the east side of the lake, watching carefully, until finally in a little bay in front of a small village $I$ had a glimpse of a thick head and large bill rising in the water 45 yards away and fired quickly to be rewarded by the sight of a wing in the air as my grebe, shot through the neck, turned over in the water. Although a pied-billed grebe in form and color the bird, a male, was truly huge, its size leaving no possible doubt as to its identity. On the return I saw various small grebes and finally had another quick shot at a large one, which I secured. This was a female, decidedly smaller than the male but still larger than the widely distributed Podilymbus podiceps. 
On November 10 I went out again in the forenoon and by noon had two more pairs, making six in all, with which I was content. Four were prepared as skins and two as skeletons. These large grebes seemed rather solitary and ranged alone. At a distance they were easily separated from the other species found here by much greater size, which marked them at a glance. When approached they dived and on appearing again showed only the head and the upper back. Sometimes they swam submerged into the open lake, where they were hidden by the waves and sometimes they retreated to the scanty cover of the rushes along the shore. While very quick it was my impression that they were slower than the common pied-billed grebe; they were certainly much slower in submerging than their small companions, Colymbus dominious brachypterus. The breeding season was near in the birds taken, though one female (prepared as a skeleton) was molting the wing feathers. They were not heard to call.

At the hotel one came regularly into a tiny bay where I could watch it easily. At a distance the bill appears completely white, and the body dark except on the posterior portion. When the feathers were puffed out to catch the sun the bird appeared very large indeed. Griscom's estimate of 100 pairs for the lake in 1930 seems reasonably accurate for the condition that I found in 1936 . On November $9 \mathrm{I}$ actually saw 8 birds and on November 10 between 12 and 15. My observations covered only a small part of the lake, and I did not go out on the water except on these two days.

Measurements of the four grebes preserved as skins are as follows: 2 males, wing 131.4, 139.8, culmen from base 26.0, 27.5, depth of bill at base 18.0, 18.5, tarsus 48.5, 50, middle toe with claw, 70, 70 mm.; 2 females, wing 122.8, 126, culmen from base 22.3, 22.4, depth of bill at base 15,15 , tarsus $41.4,42.1$, middle toe with claw $61.3,63$ $\mathrm{mm}$.

The larger bulk of these birds as compared with the largest individuals of Poditymbus podiceps has already been noticed, the difference being strongly marked in the skeleton. The larger skull of gigas also has stronger muscle attachments and processes, the pterygoid and the postorbital process especially being heavier. The humerus in gigas is only slightly longer and very little heavier than in the largest podiceps, and the crista superior, while larger, is very little longer, indicating a relatively weaker wing. The distal end of the humerus has the trochlea swung at a somewhat different angle in gigas.

There is no question that Podilymbus gigas is a distinct species. 


\section{Family PHAËTHONTIDAE}

PHAËTHON LEPTURUS CATESBYI Brandt: Yellow-billed Tropic-bird

Phaëthon catesbyi Brandt, Bull. Sci. Acad. Imp. St. Pétersbourg, vol. 4, 1838, col. 98 (Bermuda).

On December 5, as our ship came out of the inner bay at Puerto Barrios, three of these tropic-birds were observed diving from the wing into the water. Griscom does not include this species in his list of the birds at Guatemala.

\section{Family FREGATIDAE}

\section{FREGATA MAGNIFICENS ROTHSCHILDI Mathews}

Fregata minor rothschildi Mathews, Birds of Australia, vol. 4, 1915, p. 280 (Aruba, Dutch West Indies).

A number were flying over the harbor at Puerto Barrios on December 4 .

\section{Family ARDEIDAE}

\section{ARDEA HERODIAS Linnaeus: Great Blue Heron}

Ardea Herodias Linnaeus, Systema naturae, ed. 10, vol. 1, 1758, p. 143 (Hudson Bay).

One was recorded on Lake Atitlán November 12. While it may have been the typical form, as recorded by Griscom, there is no certainty of this as the bird was seen only at a distance.

\section{BUTORIDES VIRESCENS (Linnaeus)}

Ardea virescens Linnaeus, Systema naturae, ed. 10, vol. 1, 1758, p. 144 (South Carolina).

Green herons were seen occasionally along the shore near the hotel at Lake Atitlán from November 10 to 12.

\section{Family CATHARTIDAE}

\section{CORAGYPS ATRATUS (Bechstein)}

Vultur atratus Bechstein, Allg. Uebers., Vögel, vol. 1, Anhang, 1793, p. 655 (Florida).

While most abundant in the tropical lowlands from Puerto Barrios inland, where I saw them October 25 and December 3 and 4, zopilotes were common over the plateau region. At Antigua the birds were fairly numerous and came to rest in evening on the walls 
or trees around the azotea of the Casa Popenoe, but they disappeared at dusk. One day at noon, after the heavy air blanket of early morning had been warmed and the sun suddenly appeared black vultures flapped heavily over the houses until on the wing and then began to soar steadily upward. Several dozen remained high in the air during the entire afternoon. On clear days they were constantly overhead. I noted them in the town of Santa María de Jesús on October 31 and found them common at Dueñas, where they ranged on clear days to an elevation of 7,200 feet on Volcán de Acatenango. At Ciudad Vieja three remained daily on guard over a dead dog by the roadside from November 3 to 5 , and one still stood by to strip what it could from the bones and hide when I passed on November 8 . Zopilotes were seen in numbers at Panajachel, soaring high overhead on clear days. Here on November 12 I found half a dozen in a coffee finca where there were large trees loaded with ripening avocados. From time to time these fruits were loosened by the wind and fell to the ground to burst with a loud pop, when one of the vultures would descend to feed on the soft pulp. I saw another group of vultures watching for falling avocados on the following day, and I was told that this was regular custom with them. It is the first time I ever observed them taking regetable food.

At Chichivac, above Tecpam, numbers were noted on November 26 soaring overhead. The birds were seen regularly here in the sky, but were reported not to nest at this elevation. The highest seen were four observed in the sky above Sierra Santa Elena on November 23. The birds were said to appear here from the lowlands only during their aerial evolutions.

Zopilotes in many localities were very tame and merely moved aside to let me pass and showed the same disregard for automobiles. At the Zoological Garden in Aurora Park in Guatemala City a dozen fearlessly invaded the cage of a sleeping European brown bear in search of food.

\section{CATHARTES AURA AURA Linnaeus}

Vultur Aura Linnaeus, Systema naturae, ed. 10, vol. 1, 1758, p. 86 (Veracruz, Mexico).

The turkey vulture, often called the viuda, was widely distributed over the plateau region, though outnumbered by the black vulture at least two to one. I saw them regularly soaring over the slopes of Volcán de Acatenango near Canderas and above Dueñas on the lower slopes of Volcán de Agua above Santa María de Jesús, and near the base of Volcán de Fuego below Alotenango. At Panajachel they were seen daily near the lake, and above Tecpam I recorded $270405-41-2$ 
them at Chichivac on November 26. November 24 I saw one over the open ridges of Desconsuelo at 10,200 feet. December 3 they were fairly common along the railroad between Guatemala City and Puerto Barrios.

No indication of migration was noted so that the birds seen are supposed to be the resident form.

\section{Family ACCIPITRIDAE}

ACCIPITER STRIATUS VELOX (Wilson)

Falco velox Wilson, American ornithology, vol. 5, 1812, p. 116, pl. 45, fig. 1 (Philadelphia, Pa.).

Near Dueñas I saw one on November 3 at close range in a dry wash. At Panajachel several were noted in densely grown ravines, and on November 12 I shot an adult male. This bird had used the perch where it was secured for some time, as the ground beneath was covered with its droppings.

\section{BUTEO JAMAICENSIS (Gmelin)}

Falco jamaicensis Gmelin, Systema naturae, vol. 1, pt. 1, 1788, p. 266 (Jamaica).

At 6,500 feet on the slopes of Volcán de Acatenango, above Dueñas, on November 4 I saw a red-tailed hawk with dark head and throat and white under parts pass overhead. On November 24, at 10,500 feet at Desconsuelo, a beautiful dark bird with a red tail came to rest in the top of a tall pine but circled away screaming shrilly before I came within gun range. It is probable that the second bird was $B$. $j$. calurus, while the first may have been of this race or may have been $B . j$. costaricensis.

\section{BUTEO NITIDA MICRUS Miller and Griscom}

Buteo nitida micrus Miller and Griscom, Amer. Mus. Nov., No. 25, Dec. 7, 1921, p. 4 ( 4 miles northeast of Chinandega, Nicaragua).

On November 30 in the open woods of a coffee finca at 3,200 feet near Las Lajas on the Pacific slope below Alotenango I heard low cries from a large bird hidden in the leaves of a tree top. As I walked toward it suddenly it flew out and swooped at another that I had not seen, and both circled above the trees. Against the light they appeared in silhouette without color, and I was surprised when I shot one at long range to pick up one of these light-colored hawks. The general appearance was that of Buteo magnirostris, with rather heavy body and short tail. 
The specimen, a female with the wing measuring $345 \mathrm{~mm}$., has the gray bars of the under surface rather broad and dark in color, agreeing with the diagnosis of the subspecies micrus. The second light tail bar is quite definite, the character being one in which there is much variation. I agree with van Rossem $^{1}$ that there are no characters for maintaining Asturina as a genus apart from Buteo.

\section{CIRCUS CYANEUS HUDSONIUS (Linnaeus): Marsh Hawk}

Falco hudsonius Linnaeus, Systema naturae, ed. 12, vol. 1, 1766, p. 128 (Hudson Bay).

On December 3 one circled over open fields near Zacapa.

\section{Family PANDIONIDAE}

\section{PANDION HALIAETUS CAROLINENSIS (Gmelin): Osprey}

Falco Haliaëtos $\gamma$ carolinensis GmeLin, Systema naturae, vol. 1, pt. 1, 1788, p. 263 (South Carolina).

One was circling over the harbor at Puerto Barrios with a fish in its talons on December 2. I could see the head markings clearly, making sure that it was the race carolinensis.

\section{Family FALCONIDAE}

\section{POLYBORUS CHERIWAY AUDUBONII Cassin}

Polyborus Audubonii Cassin, Proc. Acad. Nat. Sci. Philadelphia, vol. 17, 1865, p. 2 (Florida).

On December 3 I saw one near Zacapa.

FALCO SPARVERIUS SPARVERIUS Linnaeus: Eastern Sparrow Hawk

Falco sparverius Linnaeus, Systema naturae, ed. 10, vol. 1, 1758, p. 90 (South Carolina).

The three specimens taken are migrant birds from the north, as shown by their size. These include a male from San Antonio de Aguas Calientes, 2 miles southwest of Antigua, October 29 (wing $184 \mathrm{~mm}$.), a female from Dueñas, November 8 (wing $192 \mathrm{~mm}$.), and a male from 9,500 feet elevation at Sierra Santa Elena, November 21 (wing $183 \mathrm{~mm}$.). The birds were common through the plateau country and were seen on many occasions. On November 2 I found a number along the Barranca Honda, where they rested on projecting points on the high earthen cliffs. There were a few at Sierra Santa Elena in openings in the forest, and on November 24 I saw several above 10,000 feet elevation in the open parks at Desconsuelo.

\footnotetext{
${ }^{1}$ Bull. Mus. Comp. Zoöl., vol. 77, 1934, p. 429.
} 
Identification of these specimens and some others obtained since in southeastern Mexico has led to careful examination of a large series of sparrow hawks from North America with the result that I have been forced to the conclusion that all north of the ranges of Falco s. paulus of the extreme southeastern United States and Falco s. peninsularis of the lower half of Baja California must be called Falco s. sparverius.

Laid out in series it may appear at first glance that birds from the eastern part of North America are darker than those from the west, a distinction that has been recognized for years by calling these western birds Falco s. phalaena. The darker color seems most evident in females, less so in males. On critical examination, however, it appears that the difference in color does not hold for enough individuals to allow a subspecific designation, as many eastern birds are pale and many western ones dark. There is no appreciable difference in dimensions between birds from the two areas.

In making comparisons examination has been made in turn of breeding series, of a large number of specimens in fresh plumage taken in fall, winter, and spring, and finally of a considerable number of immature individuals recently from the nest. These latter, though averaging decidedly darker, show the same variations as the adults without regard to geographic locality. Birds in fresh plumage are ordinarily darker than those taken toward the middle of the breeding season, and I believe that the lighter color of many individuals is due to actual fading, particularly of the reddish brown that is so prominent in the plumage of these falcons. Naturally this fading is more pronounced in sections of small rainfall where the light is more intense, and less so in more humid areas where the light is more diffused. The exposed perches frequented by these hawks favor this process and through it the birds would naturally become paler quickly in the sun of the arid areas of the southwest.

There is a distinct tendency toward dichromatism in this race in that many are erythristic, i. e., the reddish brown is intensified, and in the male suffuses the light band at the tip of the tail, which in others is white. Such a condition is well known in some of the tropical races. The chestnut crown cap is large, small, or absent without regard to locality.

\section{Family PHASIANIDAE}

\section{DENDRORTYX LEUCOPHRYS NICARAGUAE Miller and Griscom}

Dendrortyx leucophrys nicaraguae Miller and Griscom, Amer. Mus. Nov., No. 183, July 18, 1925, p. 1 (Jalapa, 4,000 feet elevation, Nicaragua ).

During my stay at the hospitable Sierra Santa Elena there was much talk of the elusive guachoque, as these long-tailed, forest- 
haunting quail are called, and I spent considerable time in working through rather dense rain forest in wet and mud with one or two glimpses of reddish-brown birds of fair size, or their excited calls as they rose before the dogs behind cover, as the only result. Finally, on November 27, three or four flushed from dense, low growth, and one that chanced to pass within sight among the branches was secured. Later another flew from dense second growth, and I shot it, to lose it down the slope, where we found it only after long search. The wings of this handsome bird do not make the startling roar of northern quail and grouse. The crops of the two specimens were filled with small drupes.

One of the birds taken had the skin so torn that I could preserve it only as a skeleton. The other is probably a male, though the sex organs were destroyed by shot.

These birds are rare in collections. In fact, so few have been available that definite appraisal of the characters and ranges of the forms that have been described is not now practicable, though I have seen the specimens that are found in the Academy of Natural Sciences of Philadelphia, the American Museum of Natural History, the Field Museum, and the H. B. Conover collection, in addition to those in the National Museum. In brief, the single specimen from Sierra Santa Elena agrees most closely with the form nicaraguae, the dark, slaty ear coverts and reduced amount of chestnut streaking indicating this alliance. The bird is, however, more grayish, less brown on the lower back and rump, and is uniform in that area without mottling. It is distinct from true leucophrys of the eastern highlands of Guatemala, that bird being much more heavily and extensively streaked with chestnut. This identification represents an extension of range of nicaraguae into west-central Guatemala, it having been reported previously in this direction only as far as the mountains of El Salvador.

In my opinion hypospodius of Costa Rica is not a distinct species of Dendrortyx but merely a geographic race of $D$. leucophrys, marked by the reduction of the chestnut streaking, and its restriction to the foreneck and sides on the ventral surface, the lessened amount of this streaking above, and general duller dark color.

\section{Family CHARADRIIDAE}

\section{OXYECHUS VOCIFERUS VOCIFERUS (Linnaeus): Killdeer}

Charadrius vociferus LinnaEUs, Systema naturae, ed. 10, vol. 1, 1758, p. 150 (South Carolina).

A killdeer, called in Guatemala collarejo, was taken November 24 at 10,200 feet elevation at Desconsuelo from a flock of a dozen rang- 
ing in open meadows. The birds were said to be of regular occurrence there.

\section{Family SCOLOPACIDAE \\ CAPELla DELICATA (Ord): Wilson's Snipe}

Scolopax delicata ORD, in reprint of Wilson's American ornithology, vol. 9, 1825, p. cexviii (Pennsylvania).

In a marshy meadow at 9,500 feet near Sierra Santa Elena one flushed November 17. On November 20 one was taken here from eight or ten that were seen. Another was observed on November 23, and on the following day at Desconsuelo one rose from a little cienaga at 10,200 feet.

\section{ACTITIS MACULARIA (Linnaeus): Spotted Sandpiper}

Tringa macularia Linnaeus, Systema naturae, ed. 12, vol. 1, 1766, p. 249 (Pennsylvania).

Several were seen on November 11 along the Río Panajachel above the town, and on the following day along the shore of Lake Atitlán. On December 4 they were common along the beaches at Puerto Cortez.

\section{Family LARIDAE}

\section{LARUS ATRICILLA Linnaeus: Laughing Gull}

Larus Atricilla Linnaeus, Systema naturae, ed. 10, vol. 1, 1758, p. 136 (Bahamas).

Many were seen in the harbor at Puerto Barrios, December 4.

\section{Family COLUMBIDAE}

\section{COLUmba fasciata fasciata Say: Band-tailed Pigeon}

Columba fasciata SAY, in Long's Expedition to the Rocky Mountains, vol. 2, 1823, p. 10 (Plum Creek, near Castle Rock, Douglas County, Colo.).

One was seen at 9,500 feet near Sierra Santa Elena on November 21. Above Los Encuentros a dozen circled over open hills on November 24.

ZENAIDURA MACROITRA MARGINELLA (Woodhouse): Western Mourning Dove

Ectopistes marginellus Woophous,, Proc. Acad. Nat. Sci. Philadelphia, vol. 6, 1852, p. 104 (Cross Timbers, north fork of the Canadian River, Oklahoma).

Two females collected, one at 4,800 feet elevation at the west base of Volcán de Agua near Alotenango on November 5, and one at 5,700 feet altitude at La Alameda near Chimaltenango November 7, are both typical examples of the western race marginella. Whether the eastern form figures among other sight records is uncertain. 
Around Alotenango I noted mourning doves on November 2 along the barren Barranca Honda toward the base of Volcán de Fuego, and the following day saw many flying in early morning over old cornfields. Near Panajachel from November 11 to 15 they were found in brush-grown pastures or were seen flying along the lake shore at dusk. On November 24 one flushed on an open ridge at 10,500 feet elevation at Desconsuelo. On the morning of November 29 there was much shooting at mourning doves. And on December 2 in the principal market in Guatemala City I saw a woman offering doves for sale in bundles of four, asking 6 cents a bird, or 60 cents a dozen, which probably meant that they might be purchased for 3 to 5 cents each. She had about 100 freshly killed birds. Those that I examined closely were the western race.

ZENAIDA ASIATICA ASIATICA (Linnaeus): Eastern White-winged Dove

Columba asiatica Linnaeus, Systema naturae, ed. 10, vol. 1, 1758, p. 163 (Jamaica).

Seen at Zacapa on December 3 and on a low island opposite Puerto Barrios on December 4.

Columbigallina Passerina Pallescens (Baird): Mexican Ground Dove

Chamaepelia passerina ? var. pallescens BaIrd, Proc. Acad. Nat. Sci. Philadelphia, 1859 (Jan. 12, 1860), p. 305 (Cape St. Lucas, Baja California).

Near Antigua and Dueñas these birds were distributed through the fields and along the barrancas in small numbers, usually in pairs or singly. Several were seen at Panajachel.

Griscom has noted ${ }^{2}$ that these doves from Guatemala are intermediate between pallescens and neglecta but nearer the former. A male that I shot near Dueñas on November 8 is identical with skins of neglecta from Costa Rica. A female taken at Panajachel on November 15 is similar to pallescens. An immature just from the nest was collected with the female last mentioned.

\section{Family PSITTACIDAE}

\section{ARATINGA CANICULARIS CANICULARIS (Linnaeus)}

Psittacus canicularis Linnaeus, Systema naturae, ed. 10, vol. 1, 1758, p. 98 (northwestern Costa Rica.)

At Las Lajas, at an elevation of 3,500 feet on the east base of the Volcán de Fuego, I heard the chatter of parakeets in tall trees above a coffee plantation and ciimbed laboriously up a steep slope to secure one of these birds. A dozen or so flew about in pairs in swift, direct

2 Bull. Amer. Mus. Nat. Hist., vol. 44, 1932, pp. 113-114. 
flight. In the tops of dead trees they were conspicuous but when among leaves I had difficulty in seeing them. Others were observed there on November 5 .

Bangs and Peters ${ }^{3}$ have shown that two forms are represented in this species. After examination of a good series in the National Museum it appears to me that the character separating them is found in the width of the orange-buff frontal band, this being narrow and restricted in birds from western Mexico Aratinga c. eburnirostrum (Lesson), the color usually not reaching the loral area. In the typical race canicularis the broad frontal band extends back to the anterior line of the eye, or farther, and sometimes comes down over the anterior part of the lores. The color is more restricted in young birds as has been noted by van Rossem. ${ }^{4}$ The shade of green in these birds is variable and offers no differences correlated with geographic range.

Several from Acapulco, southern Guerrero, in the National $\mathbf{M u}-$ seum are typical canicularis, so that the dividing line between this and eburnirostmum comes farther north in Guerrero, if we accept the statement of Bangs and Peters that the northern bird ranges from Guerrero to Sinaloa.

\section{ARATINGA HOLOCHLORA STRENUA (Ridgway)}

Conurus holochlorus strenuus RIDGway, Proc. Biol. Soc. Washington, vol. 28, May 27, 1915, p. 106 (Ometepe, Nicaragua).

At the Finca Chichivac (elevation 8,600 feet), above Tecpam, these parakeets came in flocks to feed in the fields of maize. Carlos Pira gave me one taken there on November 14, and two more on November 20. These last had the crops filled with corn. On November 24 at Los Arcos a dozen circled high in the air.

After examination of a fair series I agree with van Rossem that this bird is best considered a geographic race of Arating a holochlora, though Bangs and Peters ${ }^{5}$ list both holochlora and strenua in a collection made by W. W. Brown at Tapanatepec, Oaxaca, in September 1927. I should, however, hold Aratinga brevipes of Socorro Island as a distinct species because of the different wing formula (with the tenth primary shorter than the seventh, instead of vice versa as in holochlora and its races) and its isolated position. Under this the birds of this group would stand as follows:

Aratinga brevipes (Lawrence).

Aratinga holochlora holochlora (Sclater).

Aratinga holochlora brewsteri Nelson.

Aratinga holochlora strenua (Ridgway).

Aratinga holochlora rubritorques (Sclater).

${ }^{3}$ Bull. Mus. Comp. Zoöl., vol. 68, 1928, pp. 388-389.

${ }^{4}$ Field Mus. Nat. Hist., zool. ser., vol. 23, 1938, p. 204.

`Bull. Mus. Comp. Zoöl., vol. 68, 1928, p. 388. 


\section{Family CUCULIDAE}

\section{COCCYZUS ERYTHROPTHALMUS (Wilson): Black-billed Cuckoo}

Cuculus erythropthalmus WILson, American ornithology, vol. 4, 1811, p. 1, pl. 28, fig. 2 (near Philadelphia, Pa.).

A female was shot at 7,800 feet on the slopes of Volcán de Agua above Santa María de Jesús on October 31. The bird was very fat.

\section{PIAYA CAYANA THERMOPHILA Sclater}

Piaya thermophila Sclater, Proc. Zool. Soc. London, 1859 (Feb. 1860), p. 368 (Jalapa, Veracruz).

On November 29 at Las Lajas at 3,200 feet elevation below Alotenango two worked quietly through shade trees over coffee. A female taken had the back feathers very loose. On the following day I watched one for some time in this same coffee plantation. It alighted to rest quietly for a minute or two, then hopped and ran quickly across two or three branches, to stop and move the long tail up and down while it peered about in typical cuckoo fashion. After another run it reached over to take something from a clump of mistletoe. At times it was wholly quiet, but ordinarily the tail was in motion.

The specimen taken has the dark coloration typical of thermophila and shows no indication of the lighter shade of $P$. c. stirtoni van Ros. sem from El Salvador. ${ }^{6}$ After examination of a large series of thermophila I have not been able to segregate the form described by Griscom from Panamá as Piayo cayana incincta. ${ }^{7}$ The width of the subterminal black tail band on the dorsal surface of the rectrices varies considerably throughout the entire range of thermophila, being occasionally even absent on the middle pair of feathers. There is similar variation in the presence or absence of a rufescent mixture on the ventral surface of the tail.

\section{GEOCOCCYX VELOX AFFINIS Hartlaub}

Geococcyx affinis HARTLAUB, Rev. Zool., vol. 7, 1844, p. 215 (Guatemala).

One was seen near Alotenango, November 5.

\section{CROTOPHAGA SULCIROSTRIS SULCIROSTRIS Swainson}

Crotophaga sulcirostris Swarnson, Phil. Mag., new ser., vol. 1, June 1827, p. 440 (Tableland, Temascáltepec, Mexico).

At Las Lajas below Alotenango at an elevation of 3,500 feet I shot one of these birds from the top of a tall tree in a heavily wooded

\footnotetext{
- Piaya cayana stirtoni van Rossem, Trans. San Diego Soc. Nat. Hist., vol. 6, Sept. 30, 1930, p. 209 (Mount Cacaguatique, Dept. San Miguel, El Salvador).

${ }^{7}$ Piaya cayana incincta Griscom, Bull. Mus. Comp. Zoöl., vol. 72, Jan. 1932, p. 324 (Permé, Caribbean slope of Darien, eastern Panamá).

$270405-41-3$
} 
barranca and two days later secured another from a little flock in a dense growth of weeds in an old field. Both specimens were in very ragged plumage. To my ear, long familiar with the querulous calls of Crotophaga ani, the notes of this bird are quite different and decidedly more musical.

\section{Family TYTONIDAE \\ TYTO PERLATA GUATEMAlaE (Ridgway)}

Strix flammea var. Guatemalae RIDGway, in Baird and Ridgway, Bull. Essex Inst., Dec. 1873, p. 200 (Chinandega, Nicaragua ${ }^{8}$ ).

A primary feather, marked by darker color when compared with the barn owl of the United States, was found in the Barranca Honda at the foot of Volcán de Fuego, November 2.

\section{Family STRIGIDAE}

\section{SPEOTYTO CUNICULARIA HYPUGAEA (Bonaparte): Western Burrowing Owl}

Strix hypugaea Bonaparte, American ornithology, vol. 1, 1825, p. 72 (plains of the Platte River).

In a barren section of the Barranca Honda at 3,800 feet elevation below Alotenango I saw two on November 2 and shot a female.

\section{Family CAPRIMULGIDAE}

\section{CHORDEILES MINOR (Forster)}

Caprimulgus minor J. R. FonSter, A catalogue of the animals of North America, 1771, p. 13 (South Carolina).

On the evening of November 12 several flew over the lake near the Hotel Tsanyuyú.

\section{Family MICROPODIDAE}

\section{STREPTOPROCNE ZONARIS MEXICANA Ridgway}

Streptoprocne zonaris mexicana RIDGway, Proc. Biol. Soc. Washington, vol. 23, Apr. 19, 1910, p. 53 (Río Seco, near Córdoba, Veracruz, Mexico).

On November 13 near Panajachel 15 or 20 coursed with their usual amazing speed over the point of a hill high above the town. The first one that I shot fell far away into the valley and was lost. But I watched there until one came driving directly at me as I stood on the pitch of a very steep slope and killed it 50 yards away, to have it hurtle

\footnotetext{
${ }^{8}$ See Baird, Brewer, and Ridgway, History of North American Birds, vol. 3, January 1874 , p. 11.
} 
in to fall almost at my feet so great was its momentum. Raúl, my companion, said that they nested on a nearby rock cliff. Others were seen near Alotenango at 3,200 feet on November 29 and 30.

The bird taken, a male, is in partial molt. It has a wing measurement of $207 \mathrm{~mm}$. and the forehead lighter than the crown, the size and the color mentioned being characteristic of the race mexicana.

\section{STREPTOPROCNE ZONARIS ALBICINCTA (Cabanis)}

Hemiprocne albicincta Cabanis, Journ. für Orn., 1862, p. 165 (Guiana).

On November 29 near Las Lajas below Alotenango flocks of these swifts circled during the entire forenoon, sometimes high overhead, above the soaring zopilotes, and sometimes at a tantalizing distance barely beyond shotgun range. As I returned at noon I saw them lower down above some open fields at 3,900 feet and stopped my auto to watch. The first one that I shot fell far distant and was lost, but the next bird I secured.

This is a female with a wing measurement of $194 \mathrm{~mm}$. The forehead and crown are uniform sooty black, the size and this color indicating clearly the more southern form, here recorded for the first time from Guatemala, where it is probably to be regarded as a migrant wanderer. Van Rossem ${ }^{9}$ has reported a similar bird from Mount Cacaguatique, El Salvador, taken on November 21, 1925.

\section{Family TROCHILIDAE}

\section{DORICHA ENICURA (Vieillot)}

Trochilus enicurus Vieillot, Nouv. Dict. Hist. Nat., vol. 23, Sept. 1818, p. 429 ("Brazil"=Guatemala).

The only specimen taken is an adult male shot near Panajachel November 14 as it fed at flowers in a dense thicket. The flexible tail was often thrown up at a right angle with the back, as was noted also in the long-tailed males of Tilmatura, a custom that serves to protect these feathers and allow access to flowers deep-set amid twigs and leaves.

\section{TILMATURA DUPONTII DUPONTII (Lesson)}

Ornismya dupontii Lesson, Histoire naturelle des colibris, Suppl., Jan. 1832, ${ }^{10}$ p. 100, pl. 1 (Mexico).

At Panajachel on November 12 I found two pairs in a coffee finca near the lake shore and collected a male. The females rested on open twigs while the males poised in the air 5 or 6 inches distant, opening and closing the long fork in the tail, scissors fashion, while the light

\footnotetext{
${ }^{9}$ Field Mus. Nat. Hist., zool. ser., vol. 23, 1938, p. 249.

${ }^{10}$ According to C. D. Sherborn, Index animalium, pt. 9, 1926, p. 2052.
} 
glistened from the blue throat. On November 13 I took another at flowers near the village and noted that the tail was raised constantly until it formed a right angle with the line of the back. Another was secured on November 15 from a high perch on a dead twig.

Of the race xenoura of Griscom ${ }^{11}$ I have seen a pair from the type locality. The male shows the narrower chestnut bar on the outer tail feathers that is given as the principal character, when compared with a good series from Guatemala and southern Mexico. Two males in the American Museum of Natural History from Matagalpa and Quilalí, Nicaragua, surprisingly, are like the typical form.

\section{ARCHILOCHUS COLUBRIS (Linnaeus): Ruby-throated Hummingbird}

Trochilus Colubris Linnaeus, Systema naturae, ed. 10, vol. 1, 1758, p. 120 (South Carolina).

At Panajachel these northern migrants were common about flowers, so that I secured three males and a female November 11, 12, 13, and 15 .

The males had begun to molt so that a spot in the center of the throat has the new metallic red feathers of the adult plumage with one or two scattered new feathers at the side. The rectrices are still those of the juvenal plumage.

\section{SElasphorus Platycercus gUatemalae Griscom}

Selasphorus platycercus guatemalae Griscom, Proc. New England Zoöl. Club, vol. 12, Apr. 3, 1930, p. 2 (Quetzaltenango, Guatemala).

An adult male was taken about flowers at 10,000 feet elevation near the great rock María Tecum, Department of Totonicapám, November 24. This bird has the chestnut markings on axillars, sides, and inner webs of the outer rectrices as well as the small bill that mark this race from typical S. p. platycercus of farther north. It measures as follows: Wing 46.9, tail 30, culmen from base $15.7 \mathrm{~mm}$.

There is one other male in the National Museum collected by Salvin, labeled only as from Guatemala.

\section{LAMPORNIS AMETHYSTINUS SALVINI (Ridgway)}

Delattria henrica salvini RIdGway, Proc. Biol. Soc. Washington, vol. 21, Oct. 20, 1908, p. 195 (Calderas, Volcán de Fuego, Guatemala, 7,000-8,000 feet).

Near Sierra Santa Elena these were the most common hummingbirds, six being obtained between November 18 and 23. They were found about little openings in the forest where they worked about flowers with the animation customary in their family, the males

\footnotetext{
${ }^{11}$ Tilmatura dupontii xenoura Griscom, Proc. New England Zoöl. Club, vol. 13, Nov. 7 , 1932, p. 59 (Cerro Cantorál, District of Achaga, Honduras).
} 
sometimes making a rattling sound with the wings when others came near, apparently a threat. In handling them I noticed that the feathers about the gape were erectile so that they could be arranged in a moustachial form.

\section{LAMPROLAIMA RHAMI RHAMI (Lesson)}

Ornismya Rhami Lesson, Rev. Zool., vol. 1, Dec. 1838 (1839), p. 315 (Mexico).

A female taken on November 23 at Sierra Santa Elena with the abundant Lampornis was the only one recorded.

\section{COLIBRI THALASSINUS (Swainson)}

Trochilus thalassinus SwaInson, Phil. Mag., new ser., vol. 1, June 1827, p. 441 (Temascáltepec, Mexico).

The two taken include a female from 7,800 feet on the north slope of Volcán de Agua above Santa María de Jesús, shot on October 31, and a male collected at Panajachel on November 15. On the latter date several were seen along the Río Panajachel, resting on open perches on the hillsides or gleaning for insects on leaves and twigs in the thickets. I heard them giving a chirping call.

\section{AMAZILIA CYANOCEPHALA CYANOCEPHALA (Lesson)}

Ornismya cyanocephahus Lesson, Histoire naturelle des oiseaux-mouches, 1829, p. 45 ("Brazil").

A male was taken at Panajachel on November 12 as it rested quietly on a shaded twig in a coffee plantation.

While Griscom ${ }^{12}$ has listed skins from Panajachel as A. c. guatemalensis, this specimen agrees exactly with the typical race of southern Mexico in being distinctly dark green on the back, with the rump and upper tail coverts dull, not showing the light brassy bronze reflections of guatemalensis.

\section{HYLOCHARIS LEUCOTIS LEUCOTIS (Vieillot)}

Trochilus leucotis VieıLlot, Nouv. Dict. Hist. Nat., vol. 23, Sept. 1818, p. 428 $\left(\right.$ Orizaba, Veracruz ${ }^{13}$ ).

On October 29, an immature male was taken as it searched among leaves and twigs in a dark, steep-sided, wooded valley at 6,500 feet on the north slope of Volcán de Acatenango, above Dueñas. An adult male was secured on October 31 at 7,800 feet on Volcán de Agua above Santa María de Jesús, and one was seen at Panajachel on November 15. The two taken are the typical form.

\footnotetext{
${ }^{12}$ Bull. Amer. Mus. Nat. Hist., vol. 64, 1932, p. 203.

13 Designated by Griscom, Amer. Mus. Nov., No. 379, 1929, p. 11.
} 


\section{ANTHOSCENUS LONGIROSTRIS PALLIDICEPS (Gould)}

Heliomaster pallidiceps Gound, An introduction to the Trochilidae, 8vo. ed., 1861, p. 139 (Jalapa, Veracruz).

A male in breeding condition was taken in open ground at the border of a coffee plantation at 3,400 feet near Las Lajas below Alotenango on November 5.

\section{Family TROGONIDAE}

TROGON COLLARIS PUELLA Gould

Trogon puella Gould, Proc. Zool. Soc. London, 1845, p. 18 (Escuintla, Guatemala).

In a coffee finca near Las Lajas at 3,200 feet, below Alotenango, these handsome trogons were fairly common. I saw my first one on November 8 when I detected a flash of red among green leaves high above the ground. At this instant the safety lock on my hammerless stuck, and I had to return to my auto for another gun. Fifteen minutes later I came again to find the trogon still resting on the same perch. After a fall from any height trogons of this type always strike amid such a cloud of feathers that I often hesitate to pick them up since it would seem that they must be completely destroyed, but ordinarily the birds, miraculously, appear in good condition-with enough feathers so that many more may be lost during the somewhat tedious process of preparation. On November 29 these trogons were common at this same point, and half a dozen were observed in a tree laden with small fruit. One swooped petulantly at a smaller species that, however, held its ground. I shot another that I prepared for a skeleton. Not only was the skin tender but the flesh also was easily broken as fragments of muscle from ribs and legs came away at a touch from my fingers. The flesh had the same odor-to me highly disagreeable-that is found in anis.

Griscom ${ }^{14}$ has described a connecting link between this bird and T. collaris of South America.

\section{TROGON MEXICANUS MEXICANUS Swainson}

Trogon Mexicanus Swarnson, Phil. Mag., new ser., vol. 1, June 1827, p. 440 (Temascáltepec, Mexico).

This trogon was fairly common near Sierra Santa Elena from near Chichivac to the dense forests of the higher slopes. The only one taken is a male shot on November 19 by Axel Pira, Jr., in a forested area at 8,600 feet.

${ }^{14}$ Bull. Mus. Comp. Zoöl., vol. 69, 1929, pp. 162-163. 


\section{TROGON VIOLACEUS SALLAEI Bonaparte}

Trogon sallaei Bonaparte, Compt. Rend., vol. 42, 1856, p. 955 (Orizaba, Veracruz, Mexico).

On November 29 and 30 gartered trogons were common about a fig tree in fruit at an elevation of 3,200 feet below Las Lajas. The fig, of medium size, stood in a coffee finca where the growth was fairly open, and it was interesting to see eight or ten of these pretty birds flying in and out to perch among its branches.

Identification of this bird is in accordance with the treatment of Peters ${ }^{15}$ and the acceptance of van Rossem's statement ${ }^{15 a}$ as to the proper subspecific name.

\section{Family ALCEDINIDAE}

\section{MEGACERYLE ALCYON (Linnaeus): Belted Kingfisher}

Alcedo alcyon Linnaeus, Systema naturae, ed. 10, vol. 1, 1758, p. 115 (South Carolina).

Kingfishers were fairly common on the shores of Lake Atitlán on November 9 to 15 , and several were seen near Puerto Barrios on December 4. While no specimens were taken it is supposed that they were of the eastern subspecies.

\section{CHLOROCERYLE AMERICANA SEPTENTRIONALIS (Sharpe)}

Ceryle septentrionalis Sharpe, Catalogue of the birds in the British Museum, vol. 17, 1892, p. 134 (Teapa, Tabasco, Mexico).

Along the shore of Lake Atitlán these small kingfishers were common. Females were taken in the vicinity of Panajachel on November 10 and 12 . When one captured a small fish a grackle swooped at it while the kingfisher chattered in protest and dashed away holding its prey.

The two taken measure as follows: Wing 88.5, 89.8, tail 64.4, 65.0, culmen from base $45.5,48.3$, tarsus $9.8,10.5 \mathrm{~mm}$. In size these agree with septentrionalis, being distinctly larger than isthmica. They are also lighter green above and whiter below. There are other specimens from Guatemala in the National Museum that I ascribe to septentrionalis from Palín, Cajabón, and Cobán. Griscom ${ }^{16}$ considered that Guatemalan birds are intermediate but nearer to isthmica, but birds that can properly be called septentrionalis range to the south through El Salvador.

\footnotetext{
${ }^{15}$ Bull. Mus. Comp. Zoöl., vol. 69, 1929, p. 434.

15a Ibid., vol. 77, 1934, p. 392.

${ }^{16}$ Bull. Amer. Mus. Nat. Hist., vol. 44, 1932, p. 181.
} 


\section{Family MOMOTIDAE}

\section{ASPATHA GULARIS (Lafresnaye)}

Prionites gularis LAFresNaye, Rev. Zool., 1840, p. 130 (Guatemala).

On November 23, near Sierra Santa Elena, Axel Pira killed one of these curious motmots on the wing as it flew through the cypress woods at 8,600 feet elevation. On the evening of November 25 the two of us walked out along open trails to examine some holes that we had found in the hope of securing more of these strange birds. The air was chill and a thin fog lay over the mountainside, but the moon shone through sufficiently to light our way, and we used our flashlights only to avoid stepping into mudholes. Near a little gate we found a perpendicular bank of black earth 8 feet in height. The first few holes in the face of this bank yielded nothing. In the last one examined the beam of the flashlight revealed the bright eye of a little wren peering out from the far end. Leaving this place we went by obscure trails far down the mountainside to another cutbank placed in an opening in the woods. In the first hole, a shallow one, the bright eyes of a rat glistened in the light like smooth black buttons. As she dashed out she brought with her, apparently attached to her nipples, two small young, which we replaced in the tunnel. Several holes were empty, but in the last one a flexible stick brought immediately a scuttling noise and a flash of green feathers, and a motmot came out, followed at once by its companion. In our hands they made no struggle, lying limp as if nearly dead. I was interested to note how the three black marks on the "ears" and the center of the breast stood out and how the light blue of the throat gleamed in the illumination from the flashlight. The two were male and female, and with these we climbed slowly up the mountain paths past the mill to the house.

\section{MOMOTUS LESSONII LESSONII Lesson}

Momotus Lessonii Lesson, Rev. Zool., vol. 5, June 1842, p. 174 (Realejo, Nicaragua).

In a coffee finca, at 3,200 feet near Las Lajas, below Alotenango, on November 29 a Lesson's motmot flew to the limb of a tree where my first impression of it was that it was a jay. In dim light the blue of the crown was clearly visible almost as if it were luminescent. This specimen I collected. The following day in this same region I watched another for some time. It was alert, and, though it remained for some time on each perch that it sought, either the tail was in motion or the head was moving as the bird looked about. The 
tail was moved up and down, rotated slowly, or swung from side to side like the pendulum of a clock. Sometimes it was held at an angle at one side.

\section{Family RAMPHASTIDAE}

\section{AULACORHYNCHUS PRASINUS STENORHABDUS Dickey and van Rossem}

Aulacorhynchus prasinus stenorhabdus Dickey and van Rossem, Ibis, 1929, pp. 49, 52 (Cerro Los Naranjos, Volcán Santa Ana, Dept. Sonsonate, El Salvador).

On November 3, in a deeply wooded barranca at 3,500 feet near Alotenango, while I was watching a group of birds in a tall treetop, a toucanet came hopping out with twitching tail and was taken. It fell amid grass and leaves directly at my feet where for a minute I could not see it, so closely did its colors match the green of the vegetation. At Sierra Santa Elena Axel Pira, Jr., gave me the skin of one taken there in April 1936.

\section{Family PICIDAE}

\section{COLAPTES MEXICANOIDES MEXICANOIDES Lafresnaye}

Colaptes mexicanoides Lafresnaye, Rev. Zool., 1844, p. 42 (Mexico).

Near Sierra Santa Elena these handsome flickers were common along the borders of woods and trails, ranging from Chichivac at 8,600 feet upward. I saw them also at Canderas and at Patzicia and found them common above 10,200 feet at Desconsuelo. They are typical flickers in general appearance as they fly away with bounding flight, displaying their white rump patches. But most of their bigh-pitched, chattering, laughing calls are quite different from the notes of the northern species, and oniy occasionally did my ear catch a sound from them that indicated their flicker relationship. They were found often in pairs. Three were taken at Sierra Santa Elena on November 17 and 18, and two more at Desconsuelo on November 24 . One of the latter was prepared as a skeleton.

The four skins agree in dark coloration with specimens from Chiapas though the bills average a little shorter. In two males this measurement is 38.2 and $40 \mathrm{~mm}$., and in two females 36 and $37.6 \mathrm{~mm}$.

\section{CEOPHLOEUS LINEATUS SIMILIS (Lesson)}

Picus similis Lesson, Oeuvres complètes de Buffon, vol. 20, 1847, p. 204 (San Carlos, El Salvador).

Two specimens were obtained at an elevation of 3,200 feet near Las Lajas, below Alotenango, a female on November 8 and a male 
on November 30. Both birds were working quietly through tall trees in a coffee plantation.

\section{CENTURUS AURIFRONS SANTACRUZI Bonaparte}

Centurus Santa Cruzi Bonaparte, Proc. Zool. Soc. London, 1837 (June 14, 1838), p. 116 (Santa Cruz de Quiché, ${ }^{17}$ Guatemala).

This species was fairly common in the areas collected. I found a number in a coffee plantation at 3,200 feet near Las Lajas below Alotenango, and shot a male here on November 3. A female was taken November 4 in a coffee plantation near Dueñas, and I saw several in open country near Canderas the same day. As they flew away with bounding flight the white rump was prominent. Near Panajachel they were found regularly, and one was taken on November 11 .

\section{BALANOSPHYRA FORMICIVORA LINEATA Dickey and van Rossem}

Balanosphyra formicivora lineata Dickey and van Rossem, Proc. Biol. Soc. Washington, vol. 40, Jan. 8, 1927, p. 1 (Mount Cacaguatique, Dept. San Miguel, El Salvador).

On October $31 \mathrm{I}$ found two in tall dead trees in a milpa near Santa María de Jesús and secured a female. The insistent call of this bird was heard near Chimaltenango on November 7, and on November 26 near Chichivac at 8,600 feet above Tecpam several were seen among pines and oaks, and a male was taken.

These two, with a fair series from elsewhere in Guatemala, substantiate Griscom's allocation of the bird of that country to lineata. Two that I have seen from Chiapas are somewhat intermediate but are nearer $B$. $f$. formicivora.

\section{PICULUS RUBIGINOSUS MAXIMUS Griscom}

Piculus rubiginosus maximus Griscom, Amer. Mus. Nov., No. 379, Oct. 17, 1929, p. 11 (Chanquejelve, Huehuetenango, Guatemala).

Near Panajachel a male was taken on November 15 as it rested amid leaves in the top of a tree standing in a small grove.

While I have followed Griscom in identifying this bird as the race maximus, I feel that systematic understanding of the species mibiginosus is at present unsatisfactory. In Mexico and Central America these birds seem subject to much individual variation, and I am inclined to believe that too many races may have been proposed.

${ }^{17}$ Designated by Griscom, Bull. Amer. Mus. Nat. Hist., vol. 64, 1932, p. 226. 


\section{SPHYRAPICUS VARIUS VARIUS (Linnaeus): Yellow-bellied Sapsucker}

Picus varius Linnaeus, Systema naturae, ed. 12, vol. 1, 1766, p. 176 (South Carolina).

At Sierra Santa Elena on November 20 I shot a female in a dense stand of deciduous trees adjacent to a pasture at 9,500 feet. Another female was taken at 10,000 feet near María Tecum on November 24.

\section{DRYOBATES VILLOSUS SANCTORUM Nelson}

Dryobates sanctorum Nelson, Auk, Jan. 1897, p. 50 (Todos Santos, Guatemala).

At Sierra Santa Elena this woodpecker was so common that I secured 4 males and 1 female between November 17 and 23. To one accustomed to the clear white markings of the hairy woodpeckers of the North, the dull-brown under parts of these Guatemalan birds was of never-ceasing interest. In some this brown color was found also on the back, but in others the dorsal markings were nearly white. I was inclined to believe that the brown was intensified by staining from the wet, moss-grown trunks over which the birds climbed. I found them in mixed pine and deciduous forest where they worked in typical hairy woodpecker fashion. They were silent, except once when I heard a chattering call from one, suggestive of Dryobaies but differing from any of the hairy woodpeckers with which I am familiar.

\section{Family DENDROCOLAPTIDAE}

\section{LEPIDOCOLAPTES AFFINIS AFFINIS (Lafresnaye)}

Dendrocolaptes affinis LAfresnaye, Rev. Zool,, vol. 2, Apr. 1839, p. 100 (Mexico).

At Sierra Santa Elena, Axel Pira, Jr., shot one on November 17 at 9,400 feet as it moved along a tree trunk, our attention being called to it by its chattering, laughing call. I saw another there on November 27 and on November 26 shot one in mixed oak and pine woods at 8,600 feet near Chichivac.

\section{LEPIDOCOLAPTES SOULEYETII COMPRESSUS (Cabanis)}

Thripobrotus compressus Cabans, Journ. für Orn., 1861, p. 243 (Costa Rica).

Near Las Lajas at 3,200 feet elevation below Alotenango I found these birds in a coffee plantation on November 8, 29, and 30 and collected a female on the first date mentioned.

This specimen, with others in the National Museum, corroborates the statement of Brodkorb ${ }^{18}$ that birds from the Pacific slope of Guatemala are to be referred to compressus rather than to insignis as they agree with a long series of skins from Costa Rica and Nicaragua

\footnotetext{
18 Occ. Pap. Mus. Zool. Univ. Michigan, No. 369, Apr. 11, 1938, p. 3.
} 
in having the streakings of dorsal and ventral surface definitely narrowed.

\section{Family COTINGIDAE}

TITYRA SEMIFASCIATA PERSONATA Jardine and Selby

Tityra personata JARDINE and SELBY, Illustrations of ornithology, vol. 1, pt. 2, June 1827, [p. 63], pl. 24 (Reál del Monte, Hidalgo, Mexico).

These cotingas were found in a coffee plantation at Las Lajas below Alotenango at 3,200 feet elevation on November 8 (specimen), 29, and 30. They are heavy-bodied birds that fly through the treetops with bounding flight to seek high perches where they rest quietly or move about in a leisurely manner. They are easily told by the light body color and the dark markings about the head.

\section{Family PIPRIDAE}

\section{CHIROXIPHIA LINEARIS LINEARIS (Bonaparte)}

Pipra linearis Bonaparte, Proc. Zool. Soc. London, 1837 (June 14, 1838), p. 113 (Mexico).

On November 30, on my last day afield near Las Lajas below Alotenango, as I followed an overgrown road through dense, low brush in which stood scattered taller trees, I heard mellow, whistled calls from some bird that remained hidden in the dense cover. While watching I collected a bent-billed flycatcher, and after forcing a way into the thicket to get it, with some difficulty because of thorns and creepers, I continued farther to a spot that was a little more open. Here I began to whistle an imitation of the unknown notes. Answer was immediate, and in a few minutes I had glimpses of a little bird that appeared entirely black, jumping from perch to perch 3 to 5 feet above the ground. Presently opportunity for a shot offered, and after five minutes work $I$ had the bird in hand. My astonishment was great to pick up a male of this handsome manakin as I had had no glimpse of its light blue-black and bright red crown. Its eight or nine companions were not alarmed by shooting and continued their whistling so that presently I secured another.

The feet were bright orange, claws black, iris dark red, and bill black.

In short tail the two taken agree with the typical form of Mexico as restricted by Bangs and Peters. ${ }^{19}$

${ }^{10}$ Bull. Mus. Comp. Zo81., vol. 68, 1928, p. 397. 


\section{Family TYRANNIDAE}

\section{TYRANNUS VERTICALIS Say: Arkansas Kingbird}

Tyrannus verticalis $\mathbf{S}_{A \mathrm{Y}}$, in Long's Expedition to the Rocky Mountains, vol. 2, 1823, p. 60 (near La Junta, Colo.).

This migrant from the north is represented by specimens taken in open country near Dueñas (5,000 feet) and at 3,200 feet near Las Lajas, below Alotenango, both on November 29. The latter was secured from a little flock feeding at a wild fig tree in a coffee finca.

TYRANNUS VOCIFERANS Swainson: Cassin's Kingbird

Tyrannus vociferans SwaInson, Quart. Journ. Sci., vol. 20, 1826, p. 273 (Temascáltepec, Mexico).

Near Chimaltenango on November 7, on an upland at 5,700 feet, where the lanes through the milpas were bordered with pine and cypress, these birds were common. They called occasionally, usually remaining in the tops of the trees, though now and then coming down to perch on the dead stalks of standing corn. A male was taken.

PITANGUS SULPHURATUS GUATIMALENSIS (Lafresnay $\bullet$ )

Saurophagus Guatimalensis LAFresnaye, Rev. Mag. Zool., 1852, p. 462 (Guatemala ).

One was noted near Puerto Barrios on December 4.

\section{MEGARYNCHUS PITANGUA MEXICANUS (Lafresnaye)}

Scaphorhynchus mexicanus LAFresnaye, Rev. Mag. Zool., 1851, p. 473 (Mexico).

At 3,200 feet elevation below Alotenango I saw these birds on several occasions and finally, on November 30, collected a pair. They rested usually amid leafy branches in the shade trees of a coffee finca and at times seemed rather wild. In general appearance they suggest Pitangus but are less aggressive and bold. The notes also are weaker, the usual call being a rattling kee-ee-ee-ees.

\section{MYIARCHUS TUBERCULIFER LAWRENCEII (Giraud)}

Muscicapa lawrenceii GIRAUD, Description of sixteen new species of North American birds, 1841, p. 7, pl. 2, fig. 1 (“Texas,” probably Nuevo León, Mexico).

Six specimens were obtained near Las Lajas, below Alotenango, on November 5 and 8, and at Panajachel November 12 and 13. Known as juil, these birds were fairly common, being found especially in the shade trees of coffee fincas, where I often heard their plaintive calls. The birds taken do not differ from skins from eastern Mexico, the wing measurements being as follows: Four males 84.3, 84.4, 84.7, 85.9; two females $77.2,80.3 \mathrm{~mm}$. 


\section{SAYORNIS NIGRICANS AQUATICA Sclater and Salvin}

Sayornis aquatica Sclater and Salvin, Ibis, 1858, p. 119 (Dueñas, Guatemala).

On October 29 I watched a black phoebe about a water conduit at the Finca San Sebastián, near Dueñas, and remarked that in appearance, actions, and twitching tail it was an exact counterpart of the form found in California. On November 2 I recorded half a dozen about seeps of water in the barren Barranca Honda at 3,800 feet elevation near Alotenango, where that great wash comes down across the beds of volcanic ash at the eastern base of Volcán de Fuego. These birds rested with twitching tails on stones and the top of the earthen banks, calling occasionally, a faint tsip.

Two females taken on November 2 have only a feather or two on the under tail coverts tipped narrowly with white. They agree so closely with birds from Costa Rica as to give full support to the statements of van Rossem ${ }^{20}$ that there is only one form of this phoebe in Central America, which is to be known as $S . n$. aquatica.

\section{EMPIDONAX MINIMUS (Baird and Baird): Least Flycatcher}

Tyrannula minima W. M. and S. F. BAIRD, Proc. Acad. Nat. Sci. Philadelphia, 1843, p. 284 (Carlisle, Pa.).

The two specimens secured were collected at 3,200 feet elevation below Alotenango on November 3 and 8.

\section{EMPIDONAX HAMMONDII (Xantus)}

Tyrannula hammondii Xantus, Proc. Acad. Nat. Sci. Philadelphia, vol. 10, 1858, p. 117 (Fort Tejon, Calif.).

This was the most common of the genus in the areas where I worked, the birds being found regularly in thickets and open groves up to 7,600 feet, occasionally going higher. They often flitted the wings and jerked the tail and now and then gave soft calls. Specimens were taken as follows: Canderas, October 30 and November 4; Santa María de Jesús, October 31; Panajachel, November 11; and Sierra Santa Elena at 9,500 feet, November 20.

\section{EMPIDONAX AFFINIS AFFINIS (Swaingon)}

Tyrannula affinis SwaInson, Phil. Mag., new ser., vol. 1, 1827, p. 367 (maritime parts of Mexico).

The five taken were all obtained among pines at high altitudes. At Sierra Santa Elena they were fairly common, specimens being collected on November 19 and 21. At Desconsuelo on November 24 several were seen about openings in the forest at 10,200 feet, and one

${ }^{20}$ Field Mus. Nat. Hist., zool. ser., vol. 23, 1938, pp. 347-348. 
was shot. Another was secured on the same date at 10,000 feet at María Tecum. The birds were found often on low perches, sometimes only a yard above the ground. The call note was a sprightly whit whit repeated steadily.

Van Rossem has indicated that the present species, called fulvipectus in the past, is to be known as affinis. ${ }^{21}$

\section{EMPIDONAX FLAVESCENS DWIGHTI van Rossem}

Empidonax flavescens dwighti van Rossem, Auk, 1928, p. 359 (Los Esesmiles, Chalatenango, El Salvador).

On October 29 at 6,500 feet, on the north slope of Volcán de Acatenango above Dueñas, I shot a male as it rested with twitching tail on an open perch.

The beautifully clear yellowish green of this bird marks it instantly from any of its relatives that I secured. In the identification of this specimen I have had the benefit of the opinion of Robert T. Moore and of the examination of considerable material in this difficult group in his collection while he was working on these specimens in the National Museum.

\section{Myiochanes PERTinax PERTinax (Cabanis and Heine)}

Contopus pertinax Cabanis and Heine, Museum Heineanum, pt. 2, Sept. 1859, p. 72 (Jalapa, Veracruz).

The first one of these alert flycatchers was taken at 6,500 feet elevation on Volcán de Acatenango, above Dueñas on November 1. About Chimaltenango on November 7 I saw several in the cypress and other trees bordering lanes and milpas and secured another. At Panajachel two more were collected on November 11 and 12. The birds were rather wild and sought elevated lookout perches. They were called ping ping by the native boys in evident imitation of their loud notes.

The two taken at Panajachel are distinctly browner than the other two, but all are identified as pertinax. It appears probable that there are two forms united under that name at present. There is no approach in the four secured to either pallidiventris or minor.

\section{MYIOCHANES RICHARDSONII RICHARDSONII (Swainson): Western Weod Pewee}

Tyrannula Richardsonii SwaInson, in Swainson and Richardson's Fauna BorealiAmericana, pt. 2, 1831 (1832), p. 146, pl. 46 (Cumberland House, Saskatchewan).

A male taken at the edge of a coffee plantation at 3,400 feet elevation near Las Lajas, below Alotenango, has the following dimensions: Wing 85.7 , tail 60.8 , culmen from base 14.2 , tarsus $13.7 \mathrm{~mm}$. The bill 
is dark, and the under surface is extensively gray. A female taken at Panajachel, November 14, from a wire crossing a weed-grown field, agrees in color and though rather small is identified as this migrant race. It measures as follows: Wing 79.0, tail 62.6 , culmen from base 14.6, tarsus $13.1 \mathrm{~mm}$.

After a long acquaintance in life with the eastern and western wood pewees I am of the definite opinion that they are specifically distinct groups in spite of their close similarity. The call notes are entirely different. Without further evidence I cannot therefore subscribe to recent statements that make these subspecific representatives of one species. $^{22}$

\section{MYIOCHANES RICHARDSONII SORDIDULUS (Sclater)}

Contopus sordidulus Sclater, Proc. Zool. Soc. London, May 1859, p. 43 (Orizaba, Veracruz ${ }^{23}$ ).

A female collected on November 5 at 3,400 feet near Las Lajas, below Alotenango, is small in size and pale in color on throat, with the gray of the sides and breast band paler and browner above than richardsonii. It measures as follows: Wing 78.1, tail 56.6, culmen from base 13.8, tarsus $13.1 \mathrm{~mm}$. While not differing greatly in size from the female placed with richardsonii, it is distinctly different in color.

\section{MITREPHANES PHAEOCERCUS QUERCINUS Dickey and van Rossem}

Mitrephanes phaeocercus quercinus Dickey and van Rossem, Proc. Biol. Soc. Washington, vol. 40, Jan. 8, 1927, p. 2 (Mount Cacaguatíque, Dept. San Miguel, El Salvador).

On November 1 I secured a female at 6,500 feet elevation on the north face of Volcán de Acatenango. Several seen in this general region were typical small flycatchers in action, ranging on open perches in heavy forest.

While slightly intermediate, this bird is distinctly darker than $M . p$. phaeocercus of southern Mexico. There is another like it in the National Museum from Uspantán in the Department of Quiché, while a bird from Cobán, Alta Vera Paz, is phaeocercus.

\section{TYRANNISCUS VILISSIMUS VILISSIMUS (Sclater and Salvin)}

Elainia vilissima Sclater and Salvin, Ibis, 1859, p. 122, pl. 4, fig. 1 (Cobán, Alta Vera Paz, Guatemala).

Two taken on November 5 at 3,400 feet elevation near Las Lajas, below Alotenango, came with low, whistled calls to a mistletoe growing in an open tree where I shot the male. A few minutes later I

\footnotetext{
22 See Dickey and van Rossem, Field Mus. Nat. Hist., zool. ser., vol. 23, 1938, p. 371.

${ }_{23}$ See Hellmayr, Field Mus. Nat. Hist., zool. ser., vol. 13, pt. 5, 1927, p. 192.
} 
saw the female resting quietly in the sun a few feet away and secured her. The disparity in size between male and female is astonishing, the former being fully one-third larger in bulk, a difference readily evident in the following measurements: Male, wing 61.0 , tail 52.8 , culmen from base 10.2 , tarsus $18.3 \mathrm{~mm}$. f female, wing 52.2 , tail 41.1 , culmen from base 8.9 , tarsus $16.2 \mathrm{~mm}$. Both birds are in fresh plumage and agree in the depth of color in the greenish yellow of the sides and flanks.

\section{ONCOSTOMA CINEREIGULARE (Sclater)}

Todirostrum cinereigulare Sclater, Proc. Zool. Soc. London, 1856 (Jan. 26, 1857), p. 256 (Córdoba, Veracruz, Mexico).

While I was trying to follow a whistled bird call in a thicket at 3,200 feet elevation below Alotenango on November 30, a tiny flycatcher flew to a perch in open view. For the moment, intent on the other matter, I paid little attention to it until suddenly it rose to the full length of its legs and uttered a toadlike, trilling note, a call of which I had been vaguely conscious before. The call came constantly for several minutes before I caught sight of the bird again so that I could secure it, to find that it was the bent-billed flycatcher, one of the most curious of its family. The eye was brownish white.

In a good series of this bird in the United States National Museum from southern Mexico to Costa Rica there are only two from the Pacific slope, the bird from Alotenango, and a skin secured by Sumichrast at Tapana, near Santa Efigenia, Oaxaca. The skin from Alotenango, a male, does not differ from specimens from Veracruz. The second bird has an unusually large bill, but there is much variation in this and it is equalled by one specimen from eastern Honduras. I notice no color differences. This is interesting in view of the form recently proposed by Brodkorb, ${ }^{24}$ which is described as having a larger bill and greener crown with a range on the Pacific lowlands from the Isthmus of Tehuantepec to Costa Rica. Van Rossem ${ }^{25}$ records, on the other hand, that his skins from El Salvador have slightly smaller and less arched bills than those he had seen from Costa Rica.

\section{Family HIRUNDINIDAE}

NOTIOCHELIDON PILEATA (Gould)

Atticora pileata Gould, Proc. Zool. Soc. London, Nov. 9, 1858, p. 355 (Guatemala).

On the evening of November 26 Axel and Guillermo Pira brought me five of these little swallows, taken from about 30 found sleeping

\footnotetext{
24 Oncostoma cinereigulare parifica Brodkorb, Occ. Pap. Mus. Zool. Univ. Michigan, No. 401, March 1, 1939, p. 7 (Finca Esperanza, Chiapas)

${ }^{25}$ Field Mus. Nat. Hist., zool. ser., vol. 23, 1938, p. 390.
} 
in a single hole in a cutbank at an elevation of about 7,500 feet above Tecpam. At Antigua I saw them flying over the town at sunset, when at a little distance they resembled bats. Comparison of the skins secured with others from elsewhere in Guatemala indicates some variation in color of the dorsum, which, however, appears individual, some being decidedly browner than others.

\section{STELGIDOPTERYX RUFICOLLIS FULVIPENNIS (Sclater)}

Cotyle fulvipennis Sclater, Proc. Zool. Soc. London, 1859, p. 364 (Jalapa, Veracruz, Mexico).

Rough-winged swallows were common where the road crossed the wash called Barranca Honda at 3,800 feet elevation near Alotenango, along the eastern base of the Volcán de Fuego. I saw 40 or 50 here from November 2 to 8, and again on November 29 and 30 . The notes and appearance of these birds as they turned and circled in the air or rested in little groups on wires beside the road were those common to the roughwing of the United States.

On November 2 I collected two specimens. An adult male has the throat lightly washed with reddish brown, but in an immature female there is only a slight trace of this color on the chin. The latter except for the darker color of the breast and sides is closely similar to the race serripennis.

Near Panajachel on November 13 and 14 a flock of several hundred swallows mainly of this group flew over the lake in the evening and at sunset suddenly hurried away to some distant roost along the northern shore.

\section{HIRUNDO RUSTICA ERYTHROGASTER Boddaert: Barn Swallow}

Hirundo erythrogaster BodDaERT, Table des planches enluminéez, 1783, p. 45 (Cayenne).

Near Dueñas I saw a dozen circling over an open field on October 30 and observed many more on November 1,3 , and 4 . Several were noted near Alotenango on November 5. I believed that this marked a period of southward migration when they were especially common. I recorded one at Chimaltenango on November 22.

\section{Family CORVIDAE}

\section{CYANOCITTA STELLERI RIDGWAYI Miller and Griscoin}

Cyanocitta stelleri ridgwayi Miller and Griscom, Amer. Mus. Nov., No. 184, Sept. 24, 1925, p. 7 (Volcán de Fuego, Guatemala).

This jay, known as chara, was the commonest species of its family in the highland regions of Guatemala. Its range was higher in the 
main than that of Cissilopha m. melanocyanea, but there was some overlap between 5,500 and 6,500 feet when the two species occasionally were found in the same woodlands.

On the higher slopes of Volcán de Acatenango these jays were common in dense deciduous forest around 7,500 feet and above, coming down a little lower at times in trees along the roads. Skins were obtained here on October 29 and November 4. Near Chimaltenango I shot one on November 7 from a little flock among pines at 5,700 feet, this being the lowest point at which I observed them. On November 13 I saw them on the hills above Panajachel, and at Sierra Santa Elena, where I prepared three more skins, they were common from November 17 to 27 , being especially abundant at 8,600 feet at Chichivac. There was complaint there of their depredations in fields of corn.

These birds were often noisy, a common call being a harsh shär-r-r $s h \ddot{a r}-r-r$, like that of the crested jays of the United States, but they had other calls that were unfamiliar to me. Once I heard one imitate the scream of the red-tailed hawk. They were found in little flocks that ranged from near the ground to the tops of the tallest trees.

Carlos Pira gave me the skin of a complete albino that he secured near Chichivac.

\section{APHELOCOMA UNICOLOR COELESTIS Ridgway}

Aphelocoma unicolor coelestis Ridgway, Proc. Biol. Soc. Washington, vol. 16, Sept. 30, 1903, p. 108 (San Cristóbal, Chiapas).

On November 17, in early morning, a pair of these great jays came among the cypress trees near the house at Sierra Santa Elena. They moved slowly from perch to perch, appearing very large in the eddying mist. One was taken. On November 24 I recorded another, and noted that its call was much like that of the California jay, but much louder.

\section{CYANOLyCA PUMilo PUMilo (Strickland)}

Cyanocorax pumilo STrickLand, in Jardine's Contributions to ornithology, 1849, p. 122, pl. 33 (Guatemala).

On October 27 at the Cuesta San Rafaél, above Mixco, at an elevation of 7,000 feet near the boundary between Guatemala and Sacatepéquez, I had a distinct view of one of these jays in a low tree beside the road. When I stopped my car it disappeared instantly. On November 27, at 9,500 feet elevation near Sierra Santa Elena, I heard a curious call and found that it came from a pair of these birds in a grove of trees on the mountainside. A female was taken.

Examination of a small series from Chiapas and Guatemala indicates wing measurements as follows: Male 117.8; females 110, 111.8, 
111.8, 112, $114.6 \mathrm{~mm}$. Van Rossem, who has described C.p. nigrogularis ${ }^{26}$ from El Salvador, gives the range of size of his new form in males as $123-128 \mathrm{~mm}$. and in females as $117-118 \mathrm{~mm}$. There is thus a definite size difference. I doubt the color character indicated, however, as my female specimen from Sierra Santa Elena has the lower throat very black, this color extending over on to the sides of the head without break. The two forms seem thus to be separated on size.

There is in the National Museum a female from Cantorál, Honduras, taken by C. F. Underwood on February 10, 1936, that has the wing $117.6 \mathrm{~mm}$., so that it is evidently nigrogularis. Hellmayr ${ }^{27}$ has listed a male from Volcán de Puca, Honduras, and remarks on its size being larger than that of the Guatemalan bird though he lists it under C.p. pumilo. This also would appear to be nigrogularis.

CISSILOPHA MELANOCYANEA MELANOCYANEA (Hartlaub)

Garrulus (Cyanocorax) melanocyaneus Hartlaub, Rev. Zool., June 1844, p. 215 (Guatemala).

About Antigua and Dueñas these interesting jays were common and were seen constantly when I was afield. Known to the country people under the name chara, which is applied to all jays, they were found in flocks of 6 to 30 , sometimes in open forest and often in lines of trees bordering roads. Occasionally they ranged far out through the cornfields, using the scattered shrubbery along barrancas for shelter. I recorded them to 6,500 feet on the north slope of Volcán de Acatenango, which was about their upper limit, as the crested jay appeared just above. The birds call softly and querulously in tones suggesting those of young blue jays and slip about slyly. They were especially noticeable in early morning when they were often along the roads. Below Alotenango I found them common at 3,200 feet, and on November 14 I saw a flock near the Hotel Tsanyuyú at Panajachel. Three specimens were preserved as skins.

\section{Family PARIDAE}

\section{PSALTRIPARUS MELANOTIS MELANOTIS (Hartlaub)}

Parus melanotis "Sandb." HartiaUB, Rev. Zool., vol. 7, June 1844, p. 216 (Guatemala).

At Chimaltenango on November 7 I secured two at 5,700 feet from a little flock that fed near the tops of fairly tall trees in a lane of cypress bordering a milpa.

\footnotetext{
${ }^{20}$ Cyanotyca pumilo nigrogularis van Rossem, Auk, 1928, p. 363 (Los Esesmiles, Dept. Chalaltenango, El Salvador).

${ }^{27}$ Field Mus. Nat. Hist., zool. ser., vol. 13, pt. 7,1934, p. 49.
} 


\section{Family CERTHIIDAE}

\section{CERTHIA FAMILIARIS PERNIGRA Griscom}

Certhia familiaris pernigra Griscom, Ibis, 1935, p. 552 (Volcán de Fuego, Guatemala).

My first creeper was secured at Sierra Santa Elena on November 17, followed by another on November 19. On November 24, Axel Pira and I secured three at an elevation of 10,200 feet near Desconsuelo. They were found usually among pines and seemed to spend more time on the larger limbs than on the main trunks, possibly because the latter were grown so heavily with moss that the bark often was covered entirely and the birds could get no foothold.

With these five fresh skins and two older ones in the National Museum it is easily evident that the birds of Guatemala differ from C.f. alticola of southern Mexico in darker color on the back and in the faintly darker shade of the breast and abdomen. In observing these differences I was not aware that they had been noted previously by Griscom, whose name pernigra antedates nubigena under which I redescribed this race. ${ }^{28}$

\section{Family CINCLIDAE}

\section{CINCLUS MEXICANUS ANTHONYI Griscom}

Cinclus mexicanus anthonyi Griscom, Amer. Mus. Nov., No. 438, Dec. 15, 1930, p. 7 (8,250 feet at San Mateo, 45 miles east of Nentón, Guatemala).

On November 24 , as I drove across the bridge at Los Arcos, in the Department of Quiché, en route to Desconsuelo, I heard the sharp note of a dipper and pulled off the highway to stop at once. The Río Los Arcos there, at 7,700 feet elevation, was only 6 to 10 feet wide, and ran swiftly over a stony bed between high banks. Two of the birds appeared, and by a fortunate shot I secured one, a female. An old Indian who appeared immediately to ask for this prize to eat was much disappointed at my refusal.

This bird measures as follows: Wing 90.7, tail 49.0, culmen from base 18.8 , tarsus $31.1 \mathrm{~mm}$.

\section{Family TROGLODYTIDAE}

\section{TROGLODYTES MUSCULUS INTERMEDIUS Cabanis}

Troglodytes intermedius Cabanis, Journ. für Orn., 1860, p. 407 (San José, Costa Rica).

I secured three specimens of the house wren, one on October 30, near Canderas, at 7,600 feet, on Volcán de Acatenango, one on October 31,

${ }^{2 s}$ Certhia familiaris nubigena Wetmore, Proc. Biol. Soc. Washington, vol. 53, Apr. 19, 1940 , p. 51 (Desconsuelo, elevation 10,200 feet, Dept. Totonicapám, Guatemala). 
above Santa María de Jesús at 7,800 feet on Volcán de Agua, and one on November 29 near Las Lajas at 3,200 feet below Alotenango. They were found in weeds or thickets along the fences bordering milpas. On November 29 one was heard singing. On December 2 one scolded me from vines over a pergola in the main plaza of Guatemala City. They were known to the natives as the churrita.

\section{TROGLODYTES RUFOCILIATUS RUFOCILIATUS Sharpe}

Troglodytes rufociliatus SHARPE, Catalogue of the Birds in the British Museum, vol. 6, 1881, p. 262 (10,000 feet elevation on Volcán de Fuego, Guatemala).

At Sierra Santa Elena these woodland wrens were fairly common, ranging from near Chichivac at 8,600 feet to the higher areas at 10,000 feet. They were found about $\operatorname{logs}_{\mathrm{s}}$ in the forest or in dense thickets and came readily at a call to peer and bob, sometimes where the light was so dim that I could barely see them as they moved. Moss-grown dead falls were particularly favored, and from such shelters they scolded me with chattering notes. On the evening of November 25, while Axel Pira, Jr., and I were searching at night for motmots in their roosting holes, we came through a little gate on a trail to a perpendicular bank of black earth 8 feet high. The first few holes in this bank that we examined were empty, but in the last one the beam of the electric torch showed the bright eye and lightcolored superciliary stripe of one of these wrens at the far end 3 feet from the entrance. A stick in the hole brought the bird into my hand, and a minute later its companion followed. The nest, whatever it may have been, was in a little depression where I could not reach it. The two secured were male and female.

At Desconsuelo on November 24 I took one at 10,200 feet among fallen branches beneath the pines.

\section{HENICORHINA LEUCOPHRYS CAPITALIS Nelson}

Henicorhina leucophrys capitalis Nelson, Auk, 1897, p. 74 (Pinabete, Chiapas).

On the north face of Volcán de Acatenango above Dueñas in a steep, heavily wooded valley I found these wood wrens fairly common and after much watching secured specimens on October 29 and November 1 . The birds lived in pairs in dense shadows near the ground where their presence was usually betrayed by their chattering calls. Sometimes three or four were encountered together. Once two appeared within 10 or 15 feet of me without particular fear, though they were adroit in resting so that a branch or a root gave them concealment. The pleasing song, without great carrying power, suggests strongly the pleasant tones of the winter wren both in tone and in method of utterance. At Panajachel on November 13 I heard one singing on 
the slopes above the town. In handling specimens I was struck by the very small size of the tail in comparison with the heavy body and strong legs.

\section{HELEODYTES ZONATUS ZONATUS (Lesson)}

Picolaptes zonatus Lesson, Centurie zoologique . .., 1832, p. 210, pl. 70 ("Californie").

These cactus wrens of Guatemala are a constant surprise to one who has come to know the genus through the species of the arid sections of the southwestern United States. To follow a flock of birds superficially like ours through heavy undergrowth in a mountain forest where all vegetation is dripping with moisture is new experience, and it is difficult to establish mental association of these southern wrens with their cousins of the arid scrubs and desert sunshine of northern regions.

My first individuals I found on October 30 at 7,600 feet on the slopes of Volcán de Acatenango above Canderas in dense forest, where they were shy and elusive. Others were seen in heavy growth above a little stream near Chimaltenango on November 7, and on November 11 I found others in a dense thicket on a hillside back of Panajachel. On November 21 I followed a little band of four or five over a steep, brush-grown slope at Sierra Santa Elena at 9,500 feet, to emerge after half an hour soaking wet with no specimens, but on November 26 at Chichivac I collected two.

These wrens are found in bands of four to seven or eight that keep close together under cover, where attention is drawn to them by their chattering, scolding calls. They are usually shy but may be decoyed by a careful imitation of their notes. They move alertly, climbing along limbs and branches, searching in moss and epiphytes. At such times the tail hangs loosely, and the birds seem entirely intent on food. They were known to the boys as chorcha, and to the Indians at Sierra Santa Elena as sorojoj. The iris is pale brownish gray, and the feet and tarsi are olive yellow.

The five specimens preserved as skins are all of the typical form. Hellmayr ${ }^{29}$ is in error in not recognizing $H$. z. restrictus, which, from specimens in the National Museum, is easily distinguished.

\section{Family MIMIDAE}

\section{DUMETELLA CAROLINENSIS (Linnaeus): Catbird}

Muscicapa carolinensis LinNAEUs, Systema naturae, ed. 12, vol. 1, 1766, p. 328 (Virginia).

Common on December 4 near the beach on a small island opposite Puerto Barrios.

${ }^{29}$ Field Mus. Nat. Hist., zool. ser., vol. 13, pt. 7, 1934, p. 139. 
Melanotis hypoleucus Hartlaub, Rev. Mag. Zool., ser. 2, vol. 4, Oct. 1852, p. 460 (Guatemala).

On October 30 at 7,600 feet above Canderas on the slopes of Volcán de Acatenango I shot a dark-colored bird of thrasher form as it moved among branches in dense brush and was much surprised to find the white breast of this species when I picked it up. On November 1 at 6,500 feet above Dueñas on the same mountain I saw two or three slipping like shadows through damp, somber undergrowth and secured another. Others were taken and seen on November 13, and 14 in thickets about Panajachel. Here I identified the song, in tone and form suggestive of the brown thrasher (Toxostoma rufum), but with occasional thrushlike calls. Many of the notes were in couplets of typical thrasher type, but they were not given regularly, there being many pauses and changes in time. The effort was pleasing and one that I enjoyed.

The somewhat extraordinary suggestion of Hellmayr ${ }^{30}$ that this white-breasted bird should be rated as a geographic race of Melanotis caemilescens, which has the whole breast dull slaty blue, because of certain specimens of $M$. c. longirostris recorded by Nelson from the Tres Marias Islands is wholly without basis. The specimens in question are in the National Museum, and I find that all are albinistic. One with a white breast, being the one that suggests $M$. hypoleucus, has also much white on the lower back, rump, and elsewhere, and two others, which are normal in dark color below, have the ends of the primaries partly white. Obviously these are merely aberrant specimens and have no bearing in linking two species that are quite distinct.

There is in the National Museum a specimen taken by E. W. Nelson and E. A. Goldman on April 3, 1904, at Comitán, Chiapas, apparently the first record for the species from Mexico.

\section{Family TURDIDAE}

\section{TURDUS MIGRATORIUS Linnaeus}

Turdus migratorius LinNAEus, Systema naturae, ed. 12, vol. 1, 1766, p. 292 (South Carolina).

Migrant robins from the north were observed on November 3 near Dueñas, when a dozen passed high overhead, and on November 23 at 10,000 feet near Sierra Santa Elena, when I recorded two, also in flight.

${ }^{30}$ Field Mus. Nat. Hist., zool. ser., vol. 13, pt. 7, 1934, p. 304. 


\section{TURDUS RUFITORQUES Hartlaub}

Turdus (Merula) rufitorques HaRtLAub, Rev. Zool., 1844, p. 214 (Guatemala).

I found this common species first at La Alameda near Chimaltenango on November 7, when I shot a beautiful, full-plumaged male. At Sierra Santa Elena they were common and were seen regularly, specimens being taken on November 17 and 19. They were seen in open woodland, or at the edge of heavy forest, preferring most of all small openings bordered by open-branched trees. In such situations they ran about on the ground in search of food, or rested with jerking wings and tail. At any alarm they dashed into heavy cover and immediately were lost to sight. In appearance, movements, and habits they are the exact counterpart of the familiar robin Turdus migratorius of the north, and their scolding call notes, heard often from the woods at dusk, were just enough different to enable me to note the distinction. Occasionally at dusk I saw scattering flocks of 15 or 20 individuals passing through the trees to a roost. On November 24 I observed several small groups at Desconsuelo above 10,000 feet and shot a female. The bill, tarsi, and feet in adult males were honey yellow.

\section{TURDUS GRAYI UMBRINUS Griscom}

Turdus grayi umbrinus Griscom, Amer. Mus. Nov., No. 438, Dec. 15, 1930, p. 5 (Finca El Cipres, 2,300 feet, near Mazatenango, Guatemala).

At Panajachel on November 15 one flushed in a dense coffee bush, moving only to the other side, where it remained motionless, so that I was able to locate it with difficulty. Men were working in this section and the bird had learned apparently that it could pass unnoted by remaining quiet. This species is known as sinsontle de agua.

While Griscom has listed his specimens from Panajachel as Turdus g. grayi, this individual has the darker markings of umbrinus.

\section{TURDUS ASSIMILIS RUBICUNDUS (Dearborn)}

Planesticus assimilis rubicundus DeArborn, Field Mus. Nat. Hist., orn. ser., vol. 1, 1907, p. 137 (Patulul, Sololá, Guatemala).

On November 29 I shot a female in the shade trees of a coffee plantation at 3,200 feet elevation near Las Lajas, below Alotenango. Another was seen there the following day.

The specimen agrees fully with the description of this subspecies.

\section{TURDUS PLEBEJUS DIFFERENS (Nelson)}

Merula plebeia differens NeLson, Proc. Biol. Soc. Washington, vol. 14, Sept. 25, 1901, p. 175 (Pinabete, Chiapas).

Axel Pira, Jr., presented me with a skin of this bird that he had collected at Sierra Santa Elena in May 1936. I saw none alive 
The specimen agrees with the type series of differens. Turdus $p$. rafaelensis Miller and Griscom, ${ }^{31}$ though placed in the synonymy of differens by Hellmayr, ${ }^{32}$ appears to me to be easily distinguished. The original series in the American Museum of Natural History, as stated in the description, is exactly intermediate between differens and plebejus, serving as a link between these two and easily separated from either. Hellmayr has placed plebejus and its subspecies as geographic races of Turdus ignobilis of South America, but I see no basis for this, at least until intergradation can be shown. Turdus ignobilis and its relatives differ in having the lower breast, abdomen, and under tail coverts white, even in the juvenile stage of plumage with spotted breast.

\section{HYLOCICHLA GUTTATA AUDUBONI (Baird): Audubon's Hermit Thrush}

Turdus auduboni BAIRD, Review of American birds, June 1864, p. 16 (Fort Bridger Wyо.).

On November 24, near Desconsuelo, Axel Pira, Jr., shot a male among pines at 10,200 feet elevation. This bird is of large size, the wing measuring $103.5 \mathrm{~mm}$.

\section{SIALIA SIALIS GUATEMALAE Ridgway}

Sialia sialis guatemalae RIDgway, Proc. U. S. Nat. Mus., vol. 5, 1882, p. 13 (Guatemala).

Bluebirds were seen at Dueñas on November 2, near Alotenango on November 5, and near Chimaltenango on November 7. At Sierra Santa Elena they were common on open hillsides and in pasture lands dotted with trees. Five were taken there on November 17, 21, and 23. At Desconsuelo on November 24 they were fairly common over the rolling, open uplands above 10,000 feet. The birds ranged among the shrubbery low down, rested on dead trees, or flew about in little companies, in appearance being exactly like the bluebirds of the north. The ordinary call was generally similar to the fall note of the bluebird of the eastern United States but was sharper in tone.

\section{Family SYLVIIDAE}

\section{POLIOPTILA CAERULEA CAERULEA (Linnaeus)}

Motacilla caerulea Linnaeus, Systema naturae, ed. 12, vol. 1, 1766, p. 337 (Philadelphia, Pa.)

On November 8 I secured an adult female in a coffee plantation at 3,200 feet near Las Lajas, below Alotenango. The bird was wary but returned constantly to one spot so that I finally secured it.

On November 26 I saw a gnatcatcher at Chichivac above Tecpam.

${ }^{31}$ Amer. Mus. Nov., No. 183, July 18, 1925, p. 4.

${ }^{32}$ Field Mus. Nat. Hist., zool. ser., vol. 13, pt. 7, 1934, p. 391. 


\section{Family REGULIDAE}

\section{REGULUS SATRAPA AZTECUS Lawrence}

Regulus satrapa aztecus LAwrence, Ann. New York Acad. Sci., vol. 4, June 1887, p. 66 (City of Mexico).

During my work at Sierra Santa Elena I watched and listened constantly for this tiny bird, until, on November 21, I secured a fine male at 9,500 feet elevation. At Desconsuelo at 10,200 feet on November 24 I saw a number in the tall pines and shot a female. Most of them were so high in the trees that they were out of range, and were very difficult to follow because of their size. In actions and in notes they appeared to me identical with the two northern forms, but their darker color is easily evident. There are two additional males in the National Museum taken by E. W. Nelson and E. A. Goldman at Todos Santos, Huehuetenango, December 28, 1895.

While currently known under the subspecific name clarus $^{33}$ this race must be called aztecus as indicated above. Nelson ${ }^{34}$ considered the type of aztecus as merely a winter migrant of Regulus s. olivaceus. And Dearborn in his description of clarus said that he had seen this same type and also called it olivaceus. Hellmayr ${ }^{35}$ has expressed doubt in the matter and recently I have compared this type again to find that it is undoubtedly identical with the Guatemalan bird. Lawrence's name must therefore replace clarus. The type (Amer. Mus. Nat. Hist. No. 39341) is a male marked "City of Mexico" with no date but is a bird in fresh plumage taken probably in fall or winter. It is distinctly darker in dorsal color than olivaceus.

There are specimens of aztecus in the U. S. National Museum from Ajusco and Salazar, Distrito Federal, and from Parada, Oaxaca. The name aztecus was published also by Ridgway ${ }^{36}$ and attributed to Lawrence.

\section{Family VIREONIDAE \\ VIREO HUTTONI VULCANI Griscom}

Vireo huttoni vulcani Griscom, Amer. Mus. Nov., No. 438, Dec. 15, 1930, p. 3 (Quetzaltenango, 8,500 feet elevation, Guatemala).

On November 24 I shot an adult male in low bushes at 10,200 feet elevation at Desconsuelo. The eye was brown.

\footnotetext{
: Regulus satrapa clarus Dearborn, Field Mus. Nat. Hist., orn. ser., vol. 1, 1907, p. 134 (Sierra Santa Elena, Guatemala).

${ }^{34}$ Auk, 1898, p. 160.

35 Field Mus. Nat. Hist., zool. ser., vol. 13, pt. 7, 1934, pp. 511-512

30 Manual of North American birds, Sept. 1887, p. 521.
} 


\section{VIREO PALLENS SEMIFLAVUS Salvin}

Vireo semiflavus Salvin, Proc. Zool. Soc. London, 1863, p. 188 (Sakluk, Petên, Guatemala ${ }^{37}$ ).

On December 4 in swampy thickets back of the beach on a small island opposite Puerto Barrios these birds were found in pairs, and three were taken. Attention was drawn to them by a wrenlike, chattering call. In the three taken the sexual organs were not developed. The iris was brownish white.

In identifying these as semiflavus I have followed current understanding of the races of this bird, which from material at hand are not altogether clear to me. The three from Puerto Barrios have extraordinarily large bills, much larger than one from Belize, or a series from Campeche and Yucatán, equaling in this the only specimen I have seen of the duller-colored $V . p$. pahuster Moore.

\section{VIREO FLAVIFRONS Vieillot: Yellow-throated Vireo}

Vireo flavifrons Vieillot, Histoire naturelle des oiseaux de l'Amérique septentrionale, vol. 1, 1807 (1808), p. 85, pl. 54 (Eastern United States).

A female was taken on November 29 at 3,200 feet elevation near Las Lajas, below Alotenango.

\section{VIREO SOLITARIUS SOLITARIUS (Wilson): Blue-headed Vireo}

Muscicapa solitaria WrLson, American ornithology, vol. 2, 1810, p. 143, pl. 17, fig. 6 (Bartram's Woods, Philadelphia, Pa.)

A male was taken above Dueñas on November 1 , at an elevation of 6,500 feet on the north face of Volcán de Acatenango.

\section{VIREO GILVUS GILVUS (Vieillot): Eastern Warbling Vireo}

Muscicapa gilva Vienlot, Histoire naturelle des oiseaux de l'Amérique septentrionale, vol. 1, 1807 (1808), p. 65, pl. 34 (New York).

Near Panajachel these migrant vireos were common in dense groves in the valley above the village on November 11 and 15, two being taken on each of these days. On November $29 \mathrm{I}$ found a number in a coffee finca at 3,200 feet elevation near Las Lajas below Alotenango and shot two more. Here they were feeding on wild fruits and came constantly to the fruit-bearing trees, calling querulously. All taken are of the eastern race.

\footnotetext{
${ }^{37}$ Baird, Review of American birds, May 1866, pp. 367-368, examined the type of Vireo semiflavus Salvin and said that it bore the following data: Collector's No. 428, o Sakluk, Petén, Guatemala, April, 1862, O. Salvin.
} 


\section{HYLOPHILUS OCHRACEICEPS OCHRACEICEPS Sclater}

Hylophilus ochraceiceps, Sclater, Proc. Zool. Soc. London, 1859 (Feb. 1860), p. 375 (Playa Vicente, Oaxaca).

On December 4 these little birds were fairly common in swampy thickets on a low island opposite Puerto Barrios. They were quick in fluttering flights from perch to perch, but when at rest they remained quiet except for the quickly turning head. They were found in pairs, though the male and female that I collected showed no development of the sexual organs.

\section{Family COEREBIDAE}

\section{DIGLOSSA BARITULA MONTANA Dearborn}

Diglossa montana Dearborn, Field Mus. Nat. Hist., orn. ser., vol. 1, 1907, p. 125 (Sierra Santa Elena, 9,500 feet, near Tecpam, Guatemala).

Near Sierra Santa Elena these interesting birds were fairly common, being found in weeds and small bushes near the ground or higher up in vine-covered trees. They were alert and active, keeping under shelter and suggesting gnatcatchers somewhat in their mannerisms. I heard a low song, which may be written tee tee tee tee, that I attributed to this species. The three taken here include two males on November 18 and 23 and a bird in juvenal dress shot November 21. At María Tecum, where I secured a male on November 24 at 10,000 feet, one that flew below me as I stood on a knoll appeared dark blue above so that at first $I$ did not recognize it.

While the male averages darker than Diglosisa b. baritula the greater extension of the slate color on the throat seems to be the most prominent character marking montana.

I can see no justification for Hellmayr's action ${ }^{38}$ in linking the distinct Diglossa plumbea of Costa Rica as a subspecies of baritula, since the characters that join these two are of generic and not of subspecific value.

\section{Family COMPSOTHLYPIDAE}

\section{MNIOTILTA VARIA (Linnaeus): Black and White Warbler}

Motacilla varia Linnaeus, Systema naturae, ed. 12, vol. 1, 1766, p. 333 (Hispaniola).

On November 1 I saw several in a wooded valley at 6,500 feet elevation on Volcán de Acatenango above Dueñas, and on November 3 collected an adult male at 3,500 feet below Alotenango near the eastern base of Volcán de Fuego. One was recorded near Chimaltenango on November 7.

${ }^{3 s}$ Field Mus. Nat. Hist., zool. ser., vol. 13, pt. 8, 1935, p. 221. 
Sylvia peregrina WiLson, American ornithology, vol. 3, 1811, p. 83, pl. 25, fig. 2 (banks of the Cumberland River, Tenn.).

This northern migrant was common, my first specimen being one shot from a little flock working rapidly through the treetops at 7,800 feet elevation on Volcán de Agua above Santa María de Jesús. I saw one near Dueñas on November 3, and on November 8 shot one and saw others at 3,200 feet elevation below Alotenango. At Panajachel these warblers were abundant from November 11 to 15 , three being taken on November 11 and 12. They fed at ripened fruits, such as the jocote, which they perforated for the juices as they do grapes in the north, and also searched the flowers of trees. One that I shot had the throat and forehead yellow with pollen.

\section{VERMIVORA RUFICAPILLA RUFICAPILLA (Wilson) : Nashville Warbler}

Sylvia ruficapilla Wilson, American ornithology, vol. 3, 1811, p. 120, pl. 27, fig. 3 (near Nashville, Tenn.)

An immature male was taken in a thicket of dense, heavy growth near Panajachel, November 14.

\section{VERMIVORA SUPERCILIOSA SUPERCILIOSA (Hartlaub)}

Conirostrum superciliosum Hartlaub, Rev. Zool., vol. 7, 1844, p. 215 (Guatemala).

Specimens of this handsome warbler were taken at 6,500 feet elevation on Volcán de Acatenango above Dueñas on November 1, near Sierra Santa Elena on November 18 and 20, and at 10,200 feet near Desconsuelo on November 24. The birds were found in deciduous trees, sometimes where such growth was mixed with pine, often in company with little flocks of other warblers. They had the active habits of their near relatives.

\section{DENDROICA MAGNOLIA (Wilson): Magnolia Warbler}

Sylvia magnolia Wilson, American ornithology, vol. 3, 1811, p. 63, pl. 23, fig. 2 (Fort Adams, Miss.).

Below Alotenango I shot one at 3,400 feet on November 5 and one at 3,200 feet on November 29.

\section{DENDROICA NIGRESCENS (Townsend): Black-throated Gray Warbler}

Sylvia nigrescens Townsend, Journ. Acad. Nat. Sci. Philadelphia, vol. 7, Nov. 21, 1837, p. 191 (Fort William, Portland, Oreg.).

On November 1 I had a distinct view of a black-throated gray warbler in a hedge near Dueñas but did not have opportunity to collect it. I had left my car beside the road and climbed a little bank to 
take some photographs when the bird appeared near at hand. It is unfortunate that it was not secured, as there is no record for the species south of southern Mexico.

DENDROICA TOWNSENDI (Townsend): Townsend's Warbler

Sylvia Townsendi "Nuttall" Townsend, Journ. Acad. Nat. Sci. Philadelphia, vol. 7, Nov. 21, 1837, p. 191 (Fort Vancouver, Wash.).

This migrant warbler was common over a considerable area. I took my first on October 31, at 7,800 feet on Volcán de Agua above Santa María de Jesús, where these birds were found in little groves. On November 7 I shot two along a lane of cypress at 5,700 feet near Chimaltenango. The species was next seen at Panajachel, where I collected one on November 15. At Sierra Santa Elena skins were secured on November 18,19 , and 26 , the birds being especially numerous near Chichivac among the oaks. Higher up during a day of heavy fog and rain I found one feeding in bushes and even on the ground. On November 29 I recorded one at 3,200 feet elevation below Alotenango. While suggesting the black-throated green warbler in life, Townsend's warbler may be easily told by the definitely dark auricular region and the clear yellow of the breast.

\section{DENDROICA OCCIDENTALIS (Townsend) : Hermit Warbler}

Sylvia occidentalis Townsend, Journ. Acad. Nat. Sci. Philadelphia, vol. 7, Nov. 21, 1837, p. 190 (Fort Vancouver, Wash.).

At Desconsuelo on November 24 I shot one among low pines at 10,200 feet.

\section{DENDROICA VIRENS VIRENS (Gmelin): Black-throated Green Warbler}

Motacilla virens Gmelin, Systema naturae, vol. 1, pt. 2, 1789, p. 985 (Philadelphia, Pa.)

This species was taken with Townsend's warbler on October 31 in a little grove at 7,800 feet on Volcán de Agua, above Santa María de Jesús, a novel experience for one familiar with these two birds in the United States where one is characteristic of the East and the other of the West. One was seen at Panajachel on November 11, and a specimen was taken here two days later. Below Alotenango these warblers were fairly common, being taken on November 3 and 5 and seen on November 8 and 30 . The four secured are all of the typical form.

\section{SEIURUS NOVEBORANCENSIS NOTABILIS Ridgway}

Seiurus naevius notabilis RIDgway, Proc. U. S. Nat. Mus., vol. 3, 1880, p. 12 (Como Lake, Carbon County, Wyo.).

On December 4 I saw several water-thrushes of this type on a little cay opposite Puerto Barrios. They walked along the shore more or less under the protection of overhanging limbs or penetrated 
the more open sections of the swampy thickets. A male that I shot I have identified as the present race. The wing measured $78.3 \mathrm{~mm}$., and the bird is distinctly gray above.

\section{OPORORNIS TOLMIEI (Townsend) : MacGillivray's Warbler}

Sylvia Tolmiei Townsend, Narrative of a journey across the Rocky Mountains, Apr. 1839, p. 343 (Fort Vancouver, Wash.).

On October 31 I shot an immature male near the ground in a weedgrown thicket at 7,800 feet on Volcán de Agua, above Santa María de Jesús, and on November 14 secured an immature female in a weed-grown field at Panajachel.

\section{CARDELLINA RUBRIFRONS (Giraud): Red-faced Warbler}

Muscicapa rubrifrons GIRAud, Description of sixteen new species of North American birds, 1841, (p. 27), pl. 7, fig. 1 (Mexico).

On November 1 I collected two and saw others in a wooded valley at 6,500 feet elevation on the north face of Volcán de Fuego, above Dueñas. Another was secured among oaks at Chichivac above Tecpam, November 26. The birds move quickly through the trees feeding in usual warbler fashion.

In addition to these there are three other specimens from Guatemala in the National Museum. On careful comparison with a good series from the mountains of southern Arizona, southern New Mexico, and a few from northern Mexico I am not able to separate the Guatemalan specimens as Griscom has done in describing Cardellina mubrifrons bella from Chichicastenango. ${ }^{39}$ These warblers are subject to considerable wear and fading during the breeding season, which lightens their color decidedly, many from the northern group being summer birds in this condition. Griscom's specimens were taken in winter, and those in the National Museum were obtained in October and November. Laying aside the summer specimens in the northern series and using only early spring or winter birds (from northern Mexico), I am not able to detect any difference in shade of red or gray or in the diffusion of reddish wash over the under surface. It appears that all are the same.

\section{ERGATICUS VERSICOLOR (Salvin)}

Cardellina versicolor SALvin, Proc. Zool. Soc. London, 1863, p. 188, pl. 24, fig. 1 (Chilasco, Baja Vera Paz, Guatemala).

These beautiful warblers were fairly common over the mountains from 8,600 feet at Chichivac to above Sierra Santa Elena. Eight skins were taken at the latter point on November 18, 19, 20, 21, and

${ }^{30}$ Amer. Mus. Nov., No. 438, Dec. 15, 1930, p. 2. 
23 , and two were shot at 10,200 feet at Desconsuelo on November 24 . The birds ranged in deciduous growth and in the pines, often in company with migrant warblers from the north. In the dense growth they moved quickly so that it was difficult to keep them in sight, particularly as they were prone to move behind cover, though they were less active than many other warblers. Seen against the light, they appear entirely dark, so that their lovely colors come as a vivid surprise when one appears against the dark green foliage of the trees. They were silent so far as my observation extended.

This species is so distinct in head markings from Ergatious mber that I can see no basis for Hellmayr's action ${ }^{40}$ in uniting these two as geographic races.

\section{Wilsonia PUSIlla PILeolata (Pallas): Northern Pileolated Warbler}

Motacilla pileolata PALtas, Zoographia Rosso-Asiatica, vol. 1, 1811, p. 497 (Kodiak Island, Alaska).

Through the highland portion of Guatemala this was one of the most common and widely distributed of the migrant warblers during my observations. One was seen on November 8, at 3,200 feet elevation below Alotenango, and from here they were encountered to 10,000 feet wherever there was suitable place for them. They ranged from thickets near the ground to the tops of tall trees, moving actively with constantly twitching tails and soft call notes. It is probably these call notes that have brought the name of chip (to be pronounced as in Spanish) to all of the small, yellow-breasted warblers found in Guatemala. The five specimens taken, all pileolata, were secured as follows: 6,500 feet elevation Volcán de Acatenango, above Dueñas, October 29; 3,800 feet at the eastern base of Volcán de Fuego near Alotenango, November 2; Panajachel, November 15; and Sierra Santa Elena, November 20.

\section{SETOPHAGA PICTA GUATEMAlaE Sharpe}

Setophaga guatemalae SHARPE, Catalogue of the birds in the British Museum, vol. 10,1885 , p. 417 (Guatemala).

A female was shot at 8,600 feet elevation from a tree in the garden at Chichivac on November 26.

\section{MYIOBORUS MINIATUS HELLMAYRI van Rossem}

Myioborus miniatus hellmayri vaN Rossem, Condor, 1936, p. $117^{\text {d1 }}$ (6,000 feet elevation, Volcán de Santa Ana, Department of Sonsonate, El Salvador).

In a wooded valley at 8,600 feet near Chichivac on November 26 I shot a male near the ground in rather dense growth. It moved

$4^{40}$ Field Mus. Nat. Hist., zool. ser., vol. 13, pt. 8, 1935, p. 475.

$\$ 1$ Gives a general discussion of the races north of Costa Rica. 
alertly, spreading the tail at times, suggesting a redstart though somewhat less active. Another was observed the following day in a heavily forested area at about 8,700 feet below Calabozo near Sierra Santa Elena. This bird frequented a clearing about a little house where it rested on a fence, on logs, and on other open perches.

\section{IDIOTES RUFIFRONS RUFIFRONS (Swainson)}

Setophaga rufifrons Swainson, Animals in menageries, 1838, p. 294 (Reál Arriba, Veracruz).

An immature male was taken at Panajachel. An insistent song of two or three quickly repeated notes that I heard regularly there I finally identified as from these birds. They were found in tangles of vines, thickets, and growths of weeds, where they hid instantly at any alarm.

It is probable that specimens from Guatemala are to be referred to an undescribed race, but much more material is necessary for proper understanding of the southern group in this species.

\section{BASILEUTERUS BELLI SCITULUS Nelson}

Basileuterus belli scitulus NeLson, Auk, 1900, p. 268 (Todos Santos, Huehuetenango, Guatemala).

Above Dueñas, at 6,500 feet elevation on Volcán de Acatenango, on November $1 \mathrm{I}$ found two or three of these birds in dense herbaceous growth near the ground and collected one. They were in dense shadow and worked about with low, complaining notes. At Chichivac, at 8,600 feet elevation above Tecpam, on November 26 I secured a pair as they fed actively near the ground in the shelter of broad-leaved shrubs.

The races of this species are somewhat difficult as they are based on differences in depth of color, while at the same time there is definite color range individually, specimens taken in fall and winter being darker and those in summer lighter. When this seasonal variation is understood, most of the difficulties of separating the forms disappear. There seems to be no difference in size between any of the races here recognized. A brief review follows:

Basileuterus belli belli (Giraud) :

Muscicapa belli GIRARD, Description of sixteen new species of North American birds, 1841, pl. 4, fig. 2, and text (Mount Orizaba, Veracruz ${ }^{42}$ ).

Chestnut-brown of head darker, particularly on auricular region and about eye, green of dorsal surface, and yellow of lower parts clearer.

${ }^{42}$ Fixed by Todd, Proc. U. S. Nat. Mus., vol. 74, art. 7, 1929, p. 84. 
Wing, male, 55.8-62.1 (three specimens), female, 54.2-59.7 (four specimens).

Veracruz and Oaxaca.

Birds from near Mexico City have been attributed to this race, but these I have not seen. Specimens are at hand from Orizaba and Jico, Veracruz, and from Reyes and Mount Zempoaltepec, Oaxaca.

Basileuterus belli clarus Ridgway:

Basileuterus belli clarus Ridgway, U. S. Nat. Mus. Bull. 50, pt. 2, 1902, p. 745 (mountains near Chilpancingo, Guerrero).

Chestnut-brown of head distinctly paler, particularly around eye and on auricular region; green of dorsal surface lighter, brighter; sides and flanks lighter; yellow of under surface slightly paler.

Wing, male, 59.5-62.1 (four specimens), female, 58.2-61.5 (two specimens).

Jalisco, Michoacan, Morelos, and Guerrero.

When specimens secured at the same season are compared, this race may be separated without difficulty, though it was not recognized by Todd. $^{43}$ The clearer, lighter coloration is evident throughout the plumage. One bird from Huitzilac, Morelos, while slightly intermediate, appears nearer to this race. Other specimens have been seen from San Sebastian, Jalisco, Mount Tancítaro, Michoacan, and Omilteme, and the mountains near Chilpancingo, Guerrero.

\section{Basileuterus belli scitulus Nelson:}

Basileuterus belli scitulus NeLson, Auk, 1900, p. 268 (Todos Santos, Huehuetenango, Guatemala).

Similar to $B$. $b$. belli but green of upper surface distinctly duller, more olive; sides and flanks slightly darker; yellow of underparts averaging a little lighter.

Wing, male, 56.5-65.2 (five specimens), female 59.7-60.7 (three specimens).

Chiapas and Guatemala.

There are specimens of B.b. scitulus in the U. S. National Museum from San Cristobal, Chiapas, and from Todos Santos, Uspantán, Dueñas, Calderas, and Tecpam, Guatemala.

Basileuterus belli subobscums Wetmore:

Basileuterus belli subobscurus Wetмone, Proc. Biol. Soc. Washington, vol. 53, Apr. 19, 1940, p. 52 (Cantorál, Honduras).

Similar to B. b. scitulus but definitely darker, grayer, less greenish above; duller on the sides of the neck.

Cerro Cantorál, Honduras.

Known from two specimens in the U. S. National Museum.

4s Loc. cit., pp. 83-84. 


\section{Family ICTERIDAE}

ICTERUS GALBULA (Linnaeus): Baltimore Oriole

Coracias galbula Linnaeus, Systema naturae, ed. 10, vol. 1, 1758, p. 108 (Virginia).

On October 30 I recorded three small flocks passing through the trees on the slopes of Volcán de Acatenango above Canderas, and at 7,600 feet shot an adult male in full plumage. One was seen at 3,200 feet below Alotenango on November 8 .

\section{ICTERUS BULLOCKII (Swainson): Bullock's Oriole}

Xanthornus Bullockii SwaInson, Phil. Mag., new ser., vol. 1, June 1827, p. 436 (Reál del Monte, Hidalgo, Mexico).

The first one obtained was shot on October 31 at 7,800 feet on the north slope of Volcán de Agua above Santa María de Jesús. Another was taken near Chimaltenango on November 7, and a third at Panajachel on November 12 . The latter with several others was feeding at the fruit of the jocote.

I see no reason, with the modern information in the form of specimens that is available, for considering Icterus abeillei a geographic race of Bullock's oriole. While the females and immature birds are somewhat similar the adult males are clearly and definitely distinct.

\section{ICTERUS SPURIUS (Linnaeus): Orchard Oriole}

Oriolus spurius Linnaeus, Systema naturae, ed. 12, vol. 1, 1766, p. 162 (South Carolina).

On November 14 at Panajachel I saw two in a dense thicket bordering weed-grown fields and collected an immature male. This bird was in molt about the head.

\section{CASSIDIX MEXICANUS MEXICANUS (Gmelin)}

Corvus mexicanus Gmenrn, Systema naturae, vol. 1, pt. 1, 1788, p. 375 (Mexico).

This grackle is one of the prominent birds of Guatemala, as it lives in the open, is of large size, and comes regularly about houses. At Guatemala City on October 26 and 27 and December 2 I saw numbers in plazas, even in the business section, and in the suburbs they were common. At Antigua a pair were constantly in the great cypress tree in the patio at the Popenoe house, and I believed that they were nesting. I was told that during the rainy season in August 200 or more came to roost in the shelter of this same tree.

Above Dueñas I found them in open country on the slopes of Volcán de Acatenango up to 7,300 feet, usually about houses. Near Ciudad Vieja, on November 1, a flock of 30 or 40, all females, flew 
out of a cornfield to alight in a tree where I killed two, one adult and one immature. Many seen through the cornfields of this section were in various stages of molt, some being without tails. Near Lake Atitlán they were common but were not so widely distributed as in the valley at Antigua and Dueñas. In evening I noted them in flocks of 50 or 60 along the lake shore, and saw them in flight toward some roost. On December 3 I observed many from the train between Guatemala City and Puerto Barrios, particularly along the Río Motagua.

The country people called the females sanates and the males clarineros.

\section{TANGAVIUS AENEUS AENEUS (Wagler): Red-eyed Cowbird}

Psarocolius aeneus "Lichtenst." WAGLer, Isis von Oken, vol. 22, pt. 7, July 1829, col. 758 (City of Mexico).

On November 2, near Dueñas, I found a flock of 40 or 50 feeding packed closely together on the ground beside the road. They were busily intent on their own affairs and paid little attention as I stopped the car and got out with the gun. I selected two at one side, but as I pulled the trigger the flock was disturbed and I secured 10 , a welcome series when I came to examine the birds, as they showed various stages in molt.

Van Rossem ${ }^{44}$ from a study of Wagler's type has found that aeneus is the bird currently known as involucratus and that the type locality is the City of Mexico.

\section{GYMNOSTINOPS MONTEZUMA (Lesson)}

Cacicus Montezuma Lesson, Centurie zoologique, livr. 2, Oct. 1830, p. 33, pl. 7 (Mexico).

At Puerto Barrios on December 4 half a dozen flew overhead with straight, direct flight.

C. W. Richmond in the card catalog in the division of birds, U. S. National Museum, has noted another citation for the original description, viz., Cassicus Monteruma Lesson, in Férussac's Bulletin des Sciences Naturelles et de Géologie, vol. 19, December 1829, p. 324, where reference is made to plate "8" (=plate 7) of the Centurie Zoologique published in 1830, with the notation "Espèce nouvelle et très-belle de Cacique du Mexique, à bec rouge et noir, à plumage Marron." This reference I have not seen noted elsewhere.

4 Trans. San Diego Soc. Nat. Hist., vol. 7, May 31, 1934, p. 354. 


\section{Family THRAUPIDAE \\ ChLOROSPINGUS OLIVACEUS POSTOCUlaris Cabanis}

Chlorospingus postocularis Cabanis, Journ. für Orn., 1866, p. 163 (Sierra above Costa Cuca, Guatemala).

On November 19 at Sierra Santa Elena I secured a female from a little group of four or five that fed actively in open brush near the ground. The white spot behind the eye was a prominent field mark. Another was secured in a similar situation the following day.

PIRANGA RUBRA RUBRA (Linnaeus): Summer Tanager

Fringilla rubra Linnaeus, Systema naturae, ed. 10, vol. 1, 1758, p. 181 (South Carolina).

An adult male in full red plumage was taken on November 8 in a coffee finca at 3,200 feet below Alotenango. Several were recorded near Panajachel on November 13, and a female was shot in a swampy thicket near Puerto Barrios on December 4.

\section{PIRANGA LUDOVICIANA (Wilson): Western Tanager}

Tanagra ludoviciana WiLson, American ornithology, vol. 3, 1811, p. 27, pl. 20, fig. 1 (mouth of Lolo Creek Fork of Clearwater River, western Idaho).

At Panajachel I shot two males on November 11 and a female on November 13. Several others were seen here. On November 29 and 30 I recorded others at 3,200 feet below Alotenango. Tanagers of this group were known to the country people as kitrik in obvious imitation of the call of Piranga r. rubra and P. b. sanguinolenta.

\section{PIRANGA BIDENTATA SANGUINOLENTA Lafresnaye}

Pyranga sanguinolenta LAFreSnaYe, Rev. Zool., 1838, p. 97 (Mexico).

A male was taken at 6,500 feet on the north slope of Volcán de Acatenango above Dueñas on November 1. The bird worked actively through the lower trees, its call being so similar to that of the summer tanager of the north that I mistook it for that bird until it was in my hand.

\section{THRAUPIS ABBAS (Lichtenstein)}

Tanagra Abbas Lichtenstein, Preis-Verzeichniss mexicanischer Vögel, 1830, p. 2 (Mexico).

On November 29 and 30 these tanagers were common at fig trees in a coffee finca at 3,200 feet elevation near Las Lajas, below Alotenango. They moved about singly or in groups of two or three, gathering to feed and then scattering out to other trees to rest. Among the branches their movements were rather deliberate. In flight the yellow spot on the wing was often conspicuous. In two taken on November 29 the intestine was relatively large in size. 


\section{TANAGRA ELEGANTISSIMA VINCENS (Hartert)}

Euphonia elegantissima vincens Hartert, Bull. Brit. Orn. Club, vol. 33, Dec. 23, 1913, p. 77 (San José, Costa Rica).

On November 29 and 30 I collected a beautiful pair at 3,200 feet elevation below Alotenango. The birds were found about mistletoe clumps growing in the shade trees of a coffee finca, where my attention was drawn to them by the usual high-pitched, whistled note. Both had the alimentary tract filled with seeds and pulp from mistletoe berries.

I agree with van Rossem that vincens is readily distinguished by the darker blue of the crown, and the brighter, clearer green of the dorsal area and more yellowish shade of the lower surface in the female. There is one male of vincens in the National Museum taken by Nelson and Goldman at Canjob, Chiapas, May 3, 1904, so that this race extends from extreme southern Mexico to Chiriqui. Possibly the difficulty that Griscom and Hellmayr have had in recognizing it has come from the fact that Hartert in the original description considered that vincens ranged only in Costa Rica and southward.

I consider that elegantissima has two subspecies and that these two are not geographic races of any of their relatives.

\section{Family FRINGILLIDAE}

\section{SALTATOR ATRICEPS ATRICEPS (Lesson)}

Tanagra (Saltator) atriceps Lesson, Centurie zoologique, before May 1832, p. 208, pl. 69 (Mexico).

This strong, robust species is so different in size from the smaller forms of its group that my first encounter with it was a distinct surprise. For days I heard from time to time harsh, explosive callis coming from hidden perches among the leaves at the tops of trees, but always the bird uttering them managed to slip away unseen, and I did not couple these notes with the present species, which I had seen occasionally, until November 30 when I shot a pair at 3,200 feet below Alotenango. They are alert, flying at any alarm. The plumage is harsh and firm and the bird is heavy in body.

\section{HEDYMELES LUDOVICIANA (Linnaeus): Rose-breasted Grosbeak}

Loxia ludoviciana Linnaguus, Systema naturae, ed. 12, vol. 1, 1766, p. 306 (Louisiana).

On October $29 \mathrm{I}$ shot two in the tops of low trees at 6,500 feet on Volcán de Acatenango above Dueñas, and on October 30 and November 4 they were so common near Canderas that I had to examine all treetop birds with field glasses to avoid taking more. On the last date a small flock was seen at 7,000 feet in thick brush. This seemed 
to mark a migration period, as afterward I noted only one, on November 14 at Panajachel.

\section{PASSERINA CYANEA (Linnaeus): Indigo Bunting}

Tanagra cyanea Linnaeus, Systema naturae, ed. 12, vol. 1, 1766, p. 315 (South Carolina).

Below Alotenango I shot one at 4,800 feet on November 5, and saw two at 3,200 feet on November 30. One was taken near Chimaltenango on November 7. Near Panajachel on November 13, while searching for Melozone in growths of weeds and thickets, I saw a number of indigo buntings and shot three while obtaining specimens of the other species. They were known as ruis.

\section{PASSERINA CIRIS CIRIS (Linnaeus)}

Emberiza ciris Linnaeus, Systema naturae, ed. 10, vol. 1, 1758, p. 179 (South Carolina).

Near Panajachel I secured two, a female on November 13 and an adult male the following day. One was obtained in the weed-grown thickets where I found indigo buntings and the other in a denser growth nearby. Both belong to the eastern race.

\section{SPINUS PSALTRIA COLOMBIANUS (Lafresnaye)}

Carduelis colombianus Lafresnaye, Rev. Zool., vol. 6, 1843, p. 292 (Bogotá. Colombia).

At Panajachel on November 14 I secured four from a little flock in a weed-grown field. Two adult males were nearly in breeding condition.

In view of the uncertainty relating to the distinctness of S. p. croceus, these are identified as colombianus.

\section{SPINUS NOTATUS NOTATUS (Du Bus)}

Carduelis notata Du Bus, Bull. Acad. Roy. Bruxelles, vol. 14, Aug. 1847, p. 106 (Jalapa, Veracruz).

On November 7 I saw a number along lanes and in open pastures at 5,700 feet near Chimaltenango and shot an adult female. The low, musical notes reminded me of the calls of the western goldfinch. In flight the yellow band in the wings flashed brightly.

SPINUS ATRICEPS (Salvin)

Chrysomitris atriceps SAlvin, Proc. Zool. Soc. London, 1863, p. 190 (near Quetzaltenango, Guatemala).

Two specimens of this bird, rare in collections, were taken from a little flock on November 24, at 10,200 feet at Desconsuelo. The throats were partly filled with shelled seeds. 
ATLAPETES BRUNNEI-NUCHA BRUNNEI-NUCHA (Laf resnaye)

Embernagra brunnei-nucha Lafresnaye, Rev. Zool., Apr. 1839, p. 97 (Mexico).

The present species was found at Sierra Santa Elena in the same dense, low growths inhabited by Atlapetes $g$. griseipectus but was much less common. The passage of dogs through the brush occasionally brought one into sight, but ordinarily they flew a short distance with quickly tilting flight and then disappeared into the dense cover. Occasionally one darted with set wings down some steep slope. The two obtained were shot by Axel Pira, Jr., on November 19 and 25 .

\section{ATLAPETES GUTTURALIS GRISEIPECTUS Dwight and Griscom}

Atlapetes gutturalis griseipectus Dwight and Griscom, Amer. Mus. Nov., No. 16, Sept. 9, 1921, p. 3 (Quetzaltenango, 8,500 feet, Guatemala).

At Sierra Santa Elena these birds were fairly common but were seen with some difficulty, since they frequented low growth in rather dense woodland and ordinarily seemed to move aside under cover so that they were not seen. When the dogs accompanied us into the forest and ranged through the brush these finches would sometimes flush and alight for an instant on a low perch, offering a quick shot, and it was thus that we secured our specimens. Of the seven taken on November 18, 19, 21, and 23 five were brought me by Axel Pira, Jr.

In preparing specimens I noted that the sternum was small and the wings rounded, indicating a bird of weak flight. On the other hand, the legs were strong and heavily muscled, showing activity on the ground. The stomach was large and seemed far more prominent than ordinary in the body cavity, the abdominal section of the trunk seeming especially heavy when compared with the weakmuscled anterior portion.

\section{MELOZONE BIARCUATUM (Prévost and Des Murs)}

Pyrgita biarcuata PrÉvost and Des Murs, Voyage autour du monde sur . . . la Vénus, Atlas, Oiseaux, 1846, pl. 6 (Guatemala).

On November 4 at 7,600 feet near Canderas I shot one in dense scrub, where it ranged low down near the ground. Others were seen there, but this was the only opportunity that I had to take one. Near Panajachel where the birds were fairly common they were known as tol. On November 12 in a weed-grown milpa near the lake shore one flushed to fly a foot or two and then dropped at once into cover. Driven out of this it crossed a little barranca to hide again. Others were seen here and finally I secured one. Another was taken on November 14 . At Sierra Santa Elena I recorded several on November 19 in low brush bordering woodland at 9,500 feet. On November 
30 I secured an immature specimen at the edge of a thicket at 3,200 ) feet below Alotenango. The white head markings give a curious effect of albinism at times as they show very prominently. The extreme shyness of this species at this season may have been due in part to the fact that all were in molt.

In a series of 10 from Guatemala I find considerable individual variation that seems to cover the characters cited by Brodkorb in describing a race from Chiapas. ${ }^{45}$ Three skins from Chicharros, Chiapas are identical with one from Laguna, Guatemala, while other Guatemalan skins have a wide range from light to dark.

\section{PIPILO MACULATUS REPETENS Griscom}

Pipilo maculatus repetens Griscom, Amer. Mus. Nov., No. 438, Dec. 15, 1930, p. 12 (Zanzon, 8,000 feet, San Marcos, Guatemala).

In the weed-grown fields at 7,800 feet above Santa María de Jesús on October 31, I heard a complaining call, to-whee, coming from dense growths, and finally secured one of these birds. On November 4 one was heard at 7,200 feet above Canderas. Near Sierra Santa Elena from November 17 to 26 they were common from 8,600 feet at Chichivac to 10,000 feet above the estancia, where there were thickets and other open places. They did not penetrate the forests. Four were taken here.

\section{AIMOPHILA RUFICAUDA CONNECTENS Griscom}

Aimophila ruficauda connectens Griscom, Amer. Mus. Nov., No. 438, Dec. 15, 1930, p. 9 (Progreso, Guatemala).

Through James H. Kempton, of the U. S. Bureau of Plant Industry, I have received two specimens taken on December 8, 1937, at Los Chilamates, Jutiapa, by Raymond Stadelman that represent a new locality for this bird. These two while near connectens are definitely darker above and may be found to represent an undescribed form. They are decidedly darker than $A$. r. ruficauda, being more olivaceous and less rufescent, with the flanks darker and duller.

\section{JUNCO ALTICOLA Salvin}

Junco alticola Salvin, Proc. Zool. Soc. London, 1863, p. 189 (Volcán de Fuego, Guatemala).

At Sierra Santa Elena these interesting juncos were common from November 17 to 28 , ranging from 8,600 feet at Chichivac to 10,000 feet over the summit of the mountain. Their habits and appearance are typical of the northern forms of the group, from the flash of

45 Melozone biarcuatum hartwegi Brodkorb, Occ. Pap. Mus. Zool. Univ. Michigan, No. 369, Apr. 11, 1938, p. 6 (Finca Esperanza, 150 meters elevation, Chiapas). 
white in the tail as they flush to their habit of flying up from the ground into the woods to rest in trees when alarmed. They ranged in little flocks along the borders of heavy woods and at the house came familiarly into the garden to feed on strawberries or walk about on the floor of the verandah where I could watch them from the windows. Fallen treetops furnished a cover to which they were partial, and from these they flew up to hide motionless in the dense cover of cypress and pines. At Desconsuelo on November 24 they were common in fairly open woodland at 10,200 feet, and on open grassy slopes 300 feet higher I found them in pairs and little groups in low bushes beneath scattered deciduous trees. Here they flew up into the treetops to hide among the abundant parasitic plants that lined the limbs. On this same day at María Tecum, on the slopes below the great sacred rock of the Indians, juncos were present in the weeds and low bushes in dozens, being far more abundant here than at any other spot that I visited. They also came familiarly about the ranchos of the Indians, entering deserted houses without fear.

All were in excellent plumage at this season, and six skins were prepared. Whether this bird is to be treated as a geographic race of Junco phaeonotus is a matter still for decision.

The iris in Junco alticola is deep golden-yellow.

\section{ZONOTRICHIA CAPENSIS SEPTENTRIONALIS Griscom}

Zonotrichia capensis septentrionalis Griscom, Amer. Mus. Nov., No. 438, Dec. 15, 1930, p. 12 (Chichicastenango, Guatemala).

Specimens were taken near Chimaltenango on November 7, Panajachel on November 14, and Chichivac above Tecpam on November 26. I saw several on Volcán de Agua above Santa María de Jesús on October 31.

On my first evening in Antigua, looking at the patio in front of my room with its single towering cypress and its clumps of bushes, I hoped for a "chingolo" and in the morning I awakened to its familiar, sweetly plaintive song, a pleasure that came almost daily during my stay. Here in Guatemala the birds were known as coronadas or coronalitas. 


\section{$2 \mathrm{BHL}$ Biodiversity Heritage Library}

Wetmore, Alexander. 1941. "Notes on birds of the Guatemalan Highlands." Proceedings of the United States National Museum 89(3105), 523-581. https://doi.org/10.5479/si.00963801.3105.523.

View This Item Online: https://www.biodiversitylibrary.org/item/32570

DOI: https://doi.org/10.5479/si.00963801.3105.523

Permalink: https://www.biodiversitylibrary.org/partpdf/26195

\section{Holding Institution}

Smithsonian Libraries

\section{Sponsored by}

Smithsonian

\section{Copyright \& Reuse}

Copyright Status: NOT_IN_COPYRIGHT

Rights: https://www.biodiversitylibrary.org/permissions/

This document was created from content at the Biodiversity Heritage Library, the world's largest open access digital library for biodiversity literature and archives. Visit BHL at https://www.biodiversitylibrary.org. 